\title{
Constraints on Alpine Fault (New Zealand) mylonitization temperatures and the geothermal gradient from Ti-in-quartz thermobarometry
}

\author{
Steven B. Kidder ${ }^{1}$, Virginia G. Toy ${ }^{2}$, David J. Prior ${ }^{2}$, Timothy A. Little ${ }^{3}$, Ashfaq Khan ${ }^{1}$, and Colin MacRae \\ ${ }^{1}$ Department of Earth and Atmospheric Science, City College New York, New York, 10031, USA \\ ${ }^{2}$ Department of Geology, University of Otago, Dunedin, New Zealand \\ ${ }^{3}$ School of Geography, Environment and Earth Sciences, Victoria University of Wellington, Wellington, New Zealand \\ ${ }^{4}$ CSIRO Mineral Resources, Microbeam Laboratory, Private Bag 10, 3169 Clayton South, Victoria, Australia
}

Correspondence: Steven B. Kidder (skidder@ccny.cuny.edu)

Received: 22 February 2018 - Discussion started: 7 March 2018

Revised: 28 August 2018 - Accepted: 3 September 2018 - Published: 25 September 2018

\begin{abstract}
We constrain the thermal state of the central Alpine Fault using approximately 750 Ti-in-quartz secondary ion mass spectrometer (SIMS) analyses from a suite of variably deformed mylonites. Ti-in-quartz concentrations span more than 1 order of magnitude from 0.24 to $\sim 5 \mathrm{ppm}$, suggesting recrystallization of quartz over a $300{ }^{\circ} \mathrm{C}$ range in temperature. Most Ti-in-quartz concentrations in mylonites, protomylonites, and the Alpine Schist protolith are between 2 and $4 \mathrm{ppm}$ and do not vary as a function of grain size or bulk rock composition. Analyses of 30 large, inferredremnant quartz grains $(>250 \mu \mathrm{m})$ as well as late, crosscutting, chlorite-bearing quartz veins also reveal restricted Ti concentrations of $2-4 \mathrm{ppm}$. These results indicate that the vast majority of Alpine Fault mylonitization occurred within a restricted zone of pressure-temperature conditions where 2-4 ppm Ti-in-quartz concentrations are stable. This constrains the deep geothermal gradient from the Moho to about $8 \mathrm{~km}$ to a slope of $5^{\circ} \mathrm{C} \mathrm{km}^{-1}$. In contrast, the small grains $(10-40 \mu \mathrm{m})$ in ultramylonites have lower $\mathrm{Ti}$ concentrations of 1-2 ppm, indicating a deviation from the deeper pressuretemperature trajectory during the latest phase of ductile deformation. These constraints suggest an abrupt, order of magnitude change in the geothermal gradient to an average of about $60{ }^{\circ} \mathrm{C} \mathrm{km}^{-1}$ at depths shallower than about $8 \mathrm{~km}$, i.e., within the seismogenic zone. Anomalously, the lowest-Ti quartz $(0.24-0.7 \mathrm{ppm})$ occurs away from the fault in protomylonites, suggesting that the outer fault zone experienced minor plastic deformation late in the exhumation history
\end{abstract}

when more fault-proximal parts of the fault were deforming exclusively by brittle processes.

\section{Introduction}

The Alpine Fault is the major structure of the PacificAustralian plate boundary through New Zealand's South Island. During dextral reverse fault slip, a $<5$ million year old, $1 \mathrm{~km}$ thick mylonite zone (e.g., Sibson et al., 1979) was exhumed in the hanging wall, providing a unique exposure of deep crustal material deformed to very high strains under boundary conditions constrained by present-day plate motions (e.g., Norris and Toy, 2014). The Alpine Fault is thus a rare location where the understanding of plate boundary phenomena such as major earthquakes (Sutherland et al., 2007) or slow slip events (Chamberlain et al., 2014) can be informed by observation of rocks that recently experienced these events. Because rock deformation was recent and continues today, aspects such as total strain and strain rate (Norris and Cooper, 2003), stress levels (Liu and Bird, 2002), exhumation rates (e.g., Little et al., 2005), and depth of seismicity (Leitner et al., 2001) are known with a relatively high degree of certainty.

One poorly constrained aspect of Alpine Fault deformation is the temperature distribution at depth along the structure. The geothermal gradient is a key factor in estimating rock strength and the position of the brittle-ductile transition 
(e.g., Kohlstedt et al., 1995), interpreting exhumation rates based on radiometric ages (e.g., Batt et al., 2000) and setting boundary conditions for thermomechanical models (e.g., Batt and Braun, 1999; Herman et al., 2007) and validating their results. Some constraints on temperature are available for deep levels of the central Alpine Fault (e.g., Holm et al., 1989; Craw, 1997; Vry et al., 2004; Toy et al., 2010; Cross et al., 2015); however, estimates of temperature vary significantly, disagreeing by as much as $200^{\circ} \mathrm{C}$ at any given depth along the structure (Toy, 2007).

One tool with potential to improve the understanding of the temperature distribution along the Alpine Fault is titanium-in-quartz thermobarometry (Wark and Watson, 2006; Thomas et al., 2010). In experiments where quartz is crystallized from a Si- and Ti-saturated aqueous fluid, trace concentrations of $\mathrm{Ti}$ in quartz are observed to be a function of both temperature and pressure (Thomas et al., 2010, 2015). In both experimental and natural deformation, Ti concentrations in quartz are often reset during recrystallization (e.g., Kohn and Northrup, 2009; Behr and Platt, 2011; Kidder et al., 2013; Nachlas et al., 2014; Nachlas and Hirth, 2015). While quantifying temperatures using Ti-in-quartz thermobarometry is complicated by uncertainty in activity of $\mathrm{TiO}_{2}$ (Grujic et al., 2011; Bestmann and Pennacchioni, 2015; Nevitt et al., 2017) and differing calibrations (Huang and Audétat, 2012; Thomas et al., 2015), we find that variations in Ti-in-quartz concentrations in Alpine Fault rocks span a range large enough that these issues can be largely bypassed using independent constraints on maximum and minimum temperatures associated with quartz recrystallization. We have thus generated an extensive Ti-in-quartz dataset that facilitates an independent estimate of activity of $\mathrm{TiO}_{2}$ and places new constraints on the temperatures and pressures at which mylonitization occurred at deep levels of the Alpine Fault.

\section{Background}

\subsection{Geologic setting}

The Alpine Fault is a major transpressional structure extending $\sim 400 \mathrm{~km}$ along the western slopes of New Zealand's Southern Alps, connecting northeastward through the Marlborough fault zone to the Hikurangi subduction zone and to the southwest to the Puysegur subduction zone (Sutherland et al., 2000). Modern-day Alpine Fault systematics began with the onset of a transpressive phase at $\sim 5-8 \mathrm{Ma}$ along the Australia-Pacific plate boundary (e.g., Walcott, 1998; Batt et al., 2004; Cande and Stock, 2004). Mylonites formed during this period have been exhumed in the hanging wall of the Alpine Fault (Norris and Cooper, 2007). The exposed mylonites are developed in the hanging-wall Alpine Schist (referred to below as "the schist"), a complex, predominantly quartzofeldspathic assemblage also containing amphibolite and metachert. Age dating of the Alpine Schist suggests its protolith is an amalgamation of rocks formed at various times from the Carboniferous to Cretaceous (Cooper and Ireland, 2015). Barrovian metamorphic isograds in the non-mylonitic Alpine schists that are the chief protolith of the Neogeneaged mylonites likely date to the late Cretaceous (e.g., Vry et al., 2004). As the Alpine Fault is approached from the east, schist fabrics are overprinted by a classic sequence of fault rocks: protomylonites, mylonites, ultramylonites, and finally cataclasites (Sibson et al., 1979, 1981). Most of the rocks analyzed for this study are from Gaunt Creek, the site of the first drill holes for the 2011 Deep Fault Drilling Project (DFDP; e.g., Boulton et al., 2014). One sample was analyzed from Stony Creek (Fig. 1), 11 km southwest of Gaunt Creek.

\subsection{Deformation history}

Holcombe and Little (2001), Little et al. (2002a, b), and Little (2004) provide detailed microstructural descriptions of the transition from the Alpine Schist to the Alpine Fault mylonite zone. In particular, Little et al. (2002a) recognized four main deformation episodes in the schist $\left(D_{1}\right.$ to $\left.D_{4}\right)$. $D_{4}$ is Cenozoic deformation related to the evolution of the present dextrally convergent plate boundary (Neogene oblique collision between the Australian and Pacific plates) and generally reinforces earlier Mesozoic $D_{3}$ fabrics. The present schistosity outside of the Alpine mylonite zone is mostly $S_{3-4}$. $D_{4}$ includes the high-strain mylonitic fabrics within $\sim 1 \mathrm{~km}$ of the fault as well as a less conspicuous fabric resulting from distributed transpressional strain in more distal rocks. Neogene deformation incurred a vertical thickening and clockwise rotation (when viewed from the SW) and dextral shearing of the schists. The mylonitic $D_{4}$ imprint is only perceptible within $5 \mathrm{~km}$ of the Alpine Fault, where it is expressed by shortening (post garnet growth) of at least $50 \%$ in a direction perpendicular to the foliation (Holm et al., 1989; Little et al., 2002a). The mylonitic foliation $\left(S_{\mathrm{m}}\right)$ that is clearly a product of Alpine Fault-related ductile shearing is subparallel to and strengthens these earlier fabrics but results from higher strain and is thus aligned nearly parallel to the SE-dipping Alpine Fault.

Mylonitization began at depths of up to $35 \mathrm{~km}$ (Grapes, 1995; Vry et al., 2004; Little et al., 2005; Stern et al., 2007; Sutherland et al., 2007). Simple shear strains are $\gamma>150$ in the ultramylonites, as high as 120 in the mylonites, and 1222 in the protomylonites based on the thickness of offset, mylonitized pegmatite veins (Norris and Cooper, 2003). Characteristics such as boudinaged quartzose layers parallel to the shear zone and the reorientation of inherited, pre-Neogene lineations indicate that mylonitization involved ductile thinning by a factor $>3$ (Norris and Cooper, 2003; Gillam et al., 2013; Toy et al., 2013). The kinematic vorticity number $\left(W_{\mathrm{k}}\right)$ is estimated to be $0.7-0.85$ in the mylonite zone (Little et al., 2016) or higher (Toy et al., 2013). Strain in the mylonite likely had a flattening geometry, but with $S_{1}$ exceeding $S_{2}$ 


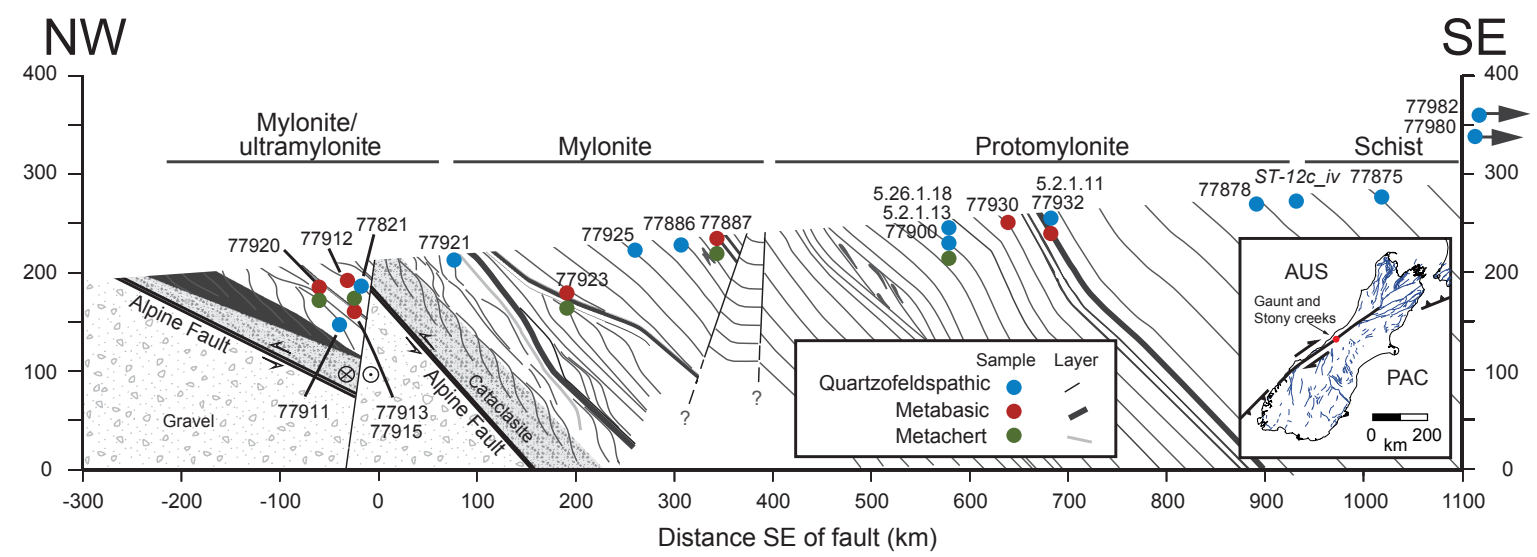

Figure 1. Schematic cross section of Gaunt Creek after Toy et al. (2008) showing approximate sample locations. Inset shows the South Island of New Zealand and the locations of Gaunt and Stony creeks. The position of the Stony Creek sample (ST-12c_iv) is projected into an approximate position based on its structural distance from the Alpine Fault.

by $\sim 30$ times (Toy et al., 2013). Strain rates were rapid and relatively well constrained at roughly $10^{-12} \mathrm{~s}^{-1}$ in the mylonite and ultramylonite zones and around $10^{-13} \mathrm{~s}^{-1}$ in the protomylonite zone based on a range of geological and plate tectonic constraints (Norris and Cooper, 2003).

\subsection{Previous temperature constraints on Alpine Fault deformation}

Thermal models indicate that rapid rates of exhumation in the hanging wall of the central Alpine Fault $\left(\sim 10 \mathrm{~mm} \mathrm{yr}^{-1}\right.$; Norris and Cooper, 2007) must significantly raise the geothermal gradient in the vicinity of the fault, especially near the surface (e.g., Koons, 1987). Direct measurements of the geothermal gradient in the upper hundreds of meters of the crust near our study area are high $\left(95^{\circ} \mathrm{C} \mathrm{km}^{-1}\right.$, Shi et al., $1996 ; 63^{\circ} \mathrm{C} \mathrm{km}^{-1}$, Sutherland et al., $2012 ; 125^{\circ} \mathrm{C} \mathrm{km}^{-1}$, Sutherland et al., 2017). Fluid inclusion evidence (e.g., Craw, 1997; Toy et al., 2010), the restriction of most earthquakes to depths $<10 \mathrm{~km}$ (Leitner et al., 2001; Boese et al., 2012; Bourguignon et al., 2015), and an observed decrease in temperature gradient near the base of the DFDP-2 borehole (Sutherland et al., 2017) indicate that the geothermal gradient is high near the surface but much lower at deeper levels (Niemeijer et al., 2016). Toy et al. (2008) and Cross et al. (2015) suggested low geothermal gradients in the ductile regime of 10 and $5^{\circ} \mathrm{C} \mathrm{km}^{-1}$, respectively.

Thermobarometric data for the Alpine Fault mylonites and Alpine schists (Cooper, 1980; Grapes and Watanabe, 1992; Grapes, 1995; Vry et al., 2004; Beyssac et al., 2016) indicate that mylonitization began at about $600{ }^{\circ} \mathrm{C}$ and $11 \mathrm{kbar}$. Toy et al. (2008) and Little et al. $(2015,2016)$ observed crystallographic preferred orientations in quartz that generally form at upper greenschist to amphibolite facies conditions $(\sim 500$ $600^{\circ} \mathrm{C}$ ). Cross et al. (2015) estimated deformation temperatures of quartz in two samples of at least $450-500^{\circ} \mathrm{C}$ based on the $c$-axis opening angle thermometer (Kruhl, 1996; Law, 2014) and microstructural evidence of subgrain rotation and grain boundary migration recrystallization in quartz (see also Little et al., 2015). The occasional presence of chlorite (generally after biotite) and green, low-Ti biotite indicates some deformation at temperatures as low as greenschist facies in protomylonites and mylonites, with changes in biotite chemistry indicating a decrease in temperature during mylonitic deformation of roughly $340^{\circ} \mathrm{C}$ (Toy et al., 2008, 2010). The amphibolite-facies metamorphic assemblage associated with mylonitization is fairly consistent in diverse rock types regardless of distance to the Alpine Fault. Chlorite is not common in the mylonites or ultramylonites, except in late-stage veins, $C^{\prime}$ shear bands, and footwall-derived ultramylonites (Toy et al., 2015).

\section{Methods}

Samples were analyzed at the California Institute of Technology, with a Cameca 7f secondary ion mass spectrometer (SIMS) using a ${ }^{16} \mathrm{O}^{-}$primary ion beam. We used a beam current of $10-15 \mathrm{nA}$, a mass-resolving power of 4000, and a field aperture of $100 \mathrm{~mm}$ and analyzed masses of ${ }^{27} \mathrm{Al},{ }^{30} \mathrm{Si}$, ${ }^{44} \mathrm{Ca},{ }^{47} \mathrm{Ti},{ }^{49} \mathrm{Ti}$, and in some samples ${ }^{56} \mathrm{Fe}$. Prior to each analysis, we rastered a $50 \times 50 \mathrm{~mm}$ area for $60 \mathrm{~s}$. Effective spot size for the analyses was about $10 \mu \mathrm{m}$. We used a regression line constrained through the origin (see Supplement) to calculate Ti concentrations using 12 analyses of National Institute of Standards (NIST) glasses 610 and $612(434 \pm 15$ and $44 \pm 5 \mathrm{ppm} \mathrm{TiO}_{2}$, respectively; Jochum et al., 2011). To account for matrix effects between quartz and NIST glass, we applied the correction factor of 0.67 determined by Behr et al. (2010). As a Ti blank, we used Herkimer "Diamond", a natural quartz containing 4-5 ppb Ti (Kidder et al., 2013). Analyses of this natural blank suggest an effective detection 
limit in this study of $78 \pm 27 \mathrm{ppb}$. No blank correction was made. The SIMS analysis routine closely follows that of Kidder et al. (2013), who successfully reproduced known Ti concentrations of two low-Ti quartz standards.

For the subset of samples where Fe was measured $(N=$ 170), nearly all of the analyses with $\mathrm{Ti}$ concentrations $>5 \mathrm{ppm}$ also have high $\mathrm{Fe} / \mathrm{Si}$ ratios $\left({ }^{56} \mathrm{Fe} /{ }^{30} \mathrm{Si}>0.007\right.$, Fig. 2). Analyses with $\mathrm{Ti}>5 \mathrm{ppm}$ were also not observed to follow any discernable patterns in cathodoluminescence (CL) intensity or position in the samples, e.g., nearer cores or rims of grains, while analyses with $\mathrm{Ti}<5 \mathrm{ppm}$ do show such patterns in many cases. We interpret that all, or nearly all, of the analyses with $\mathrm{Ti}>5 \mathrm{ppm}$ were contaminated, possibly by trace amounts of $\mathrm{Fe}$ - $\mathrm{Ti}$ oxide since small grains of $\mathrm{Fe}-$ Ti oxide are common in all of the samples. Based on these observations, all analyses with Ti concentrations $>5 \mathrm{ppm}$ or ${ }^{56} \mathrm{Fe} /{ }^{30} \mathrm{Si}>0.007$ (7\% of analyses) were removed from the dataset. We were unable to identify any clear criteria to similarly filter the data using $\mathrm{Al}$ or $\mathrm{Ca}$ concentrations.

CL images were acquired prior to SIMS analyses on most of the areas where Ti was analyzed using the Zeiss variablepressure field-emission scanning electron microscope (SEM) at the University of Otago. Images were collected using a variable-pressure secondary-electron (VPSE) detector operated at high-vacuum, $30 \mathrm{kV}$ accelerating voltage and $7 \mathrm{nA}$ beam current. This detector is sensitive in the range 300$650 \mathrm{~nm}$. Hyperspectral CL maps (MacRae et al., 2013) were acquired in one sample using a JEOL $8500 \mathrm{~F}$ electron microprobe equipped with an ocean optics QEPro spectrometer tuned to collect from 200 to $960 \mathrm{~nm}$. The sample for hyperspectral CL mapping was polished with colloidal silica, coated with $15 \mathrm{~nm}$ of carbon, and analyzed at $20 \mathrm{kV}$ accelerating voltage, $30 \mathrm{nA}$ beam current, a dwell time of $40 \mathrm{~ms}$ per pixel, and a defocused beam and pixel size of $2 \mu \mathrm{m}$. Hyperspectral CL maps were displayed and processed using the in-house software, Chimage (Leeman et al., 2012). The hyperspectral maps were fitted at each pixel using a least squares approach with a set of three Gaussian distributions: the $\mathrm{Ti}^{4+}$ peak at $470 \mathrm{~nm}$ (Leeman et al., 2012), the nearinfrared peak at $729 \mathrm{~nm}$, and the non-bridging oxygen hole center at $646 \mathrm{~nm}$ (Kalceff and Phillips, 1995).

Measurements of grain size, distance between analysis spots, and features such as grain boundaries or Ti-bearing phases were made (following SIMS analyses) using a reticle in an optical microscope. Grains were distinguished from subgrains based on the sharpness of grain boundaries under cross-polarized light. Long and short axes of elongate grains were manually measured, and reported sizes for these grains are diameters of circles with the same area as an ellipse having the measured axes lengths. In order to determine if rutile, a minor constituent in some of the rocks, is present, several hundred to several thousand bright grains in backscatter imagery were automatically characterized in each sample using energy-dispersive X-ray spectroscopy (EDS) with the Oxford

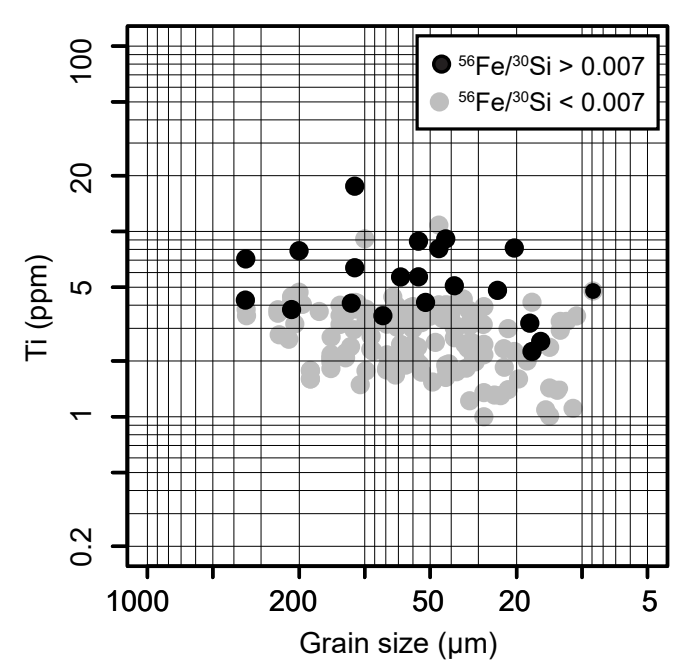

Figure 2. Plot of grain size vs. Ti showing all analyses where $\mathrm{Fe}$ was measured. Analyses with high Fe contents $\left({ }^{56} \mathrm{Fe} /{ }^{30} \mathrm{Si}\right.$ ratios $>0.007$ ) are plotted in black. The coincidence of high $\mathrm{Fe} / \mathrm{Si}$ ratios with high Ti suggests that the high-Ti analyses were contaminated by some non-quartz phase, possibly Fe-Ti oxides, which are common in the Alpine Fault mylonites. All analyses with ${ }^{56} \mathrm{Fe} /{ }^{30} \mathrm{Si}$ ratios $>0.007$ or Ti concentrations $>5 \mathrm{ppm}$ were removed from the dataset (see text for details).

Instruments particle analysis "Feature" algorithm on the University of Otago SEM.

\section{Description of samples}

\subsection{Schists and protomylonites}

Most of the quartz in the protomylonites and schists has a grain size of $20-200 \mu \mathrm{m}$, though grains as large as 2$4 \mathrm{~mm}$ are present. Larger grains commonly have patchy undulose extinction, contain subgrains, and are elongated (axial ratios from $1: 2$ to $1: 10$ ) with a distinct shapepreferred orientation (SPO). High-angle boundaries between the large quartz grains are generally interlobate. In many samples, small $(<50 \mu \mathrm{m})$ grains are prevalent adjacent to these interlobate boundaries. Feldspars form porphyroclasts and show little evidence of crystal plasticity - only weak undulose extinction and in some cases deformation twins. Since both subgrains and, more commonly, relatively large grains with interlobate high-angle grain boundaries are observed, the observed quartz microstructures resemble those near the transition of dislocation creep regimes 2 and 3 as described by Hirth and Tullis (1992) in experimentally deformed quartzites. $C^{\prime}$ shear bands, some containing a retrograde chlorite-bearing assemblage, are pervasively developed in the protomylonites (Gillam et al., 2013). These contain recrystallized quartz grains as small as $10-20 \mu \mathrm{m}$. 


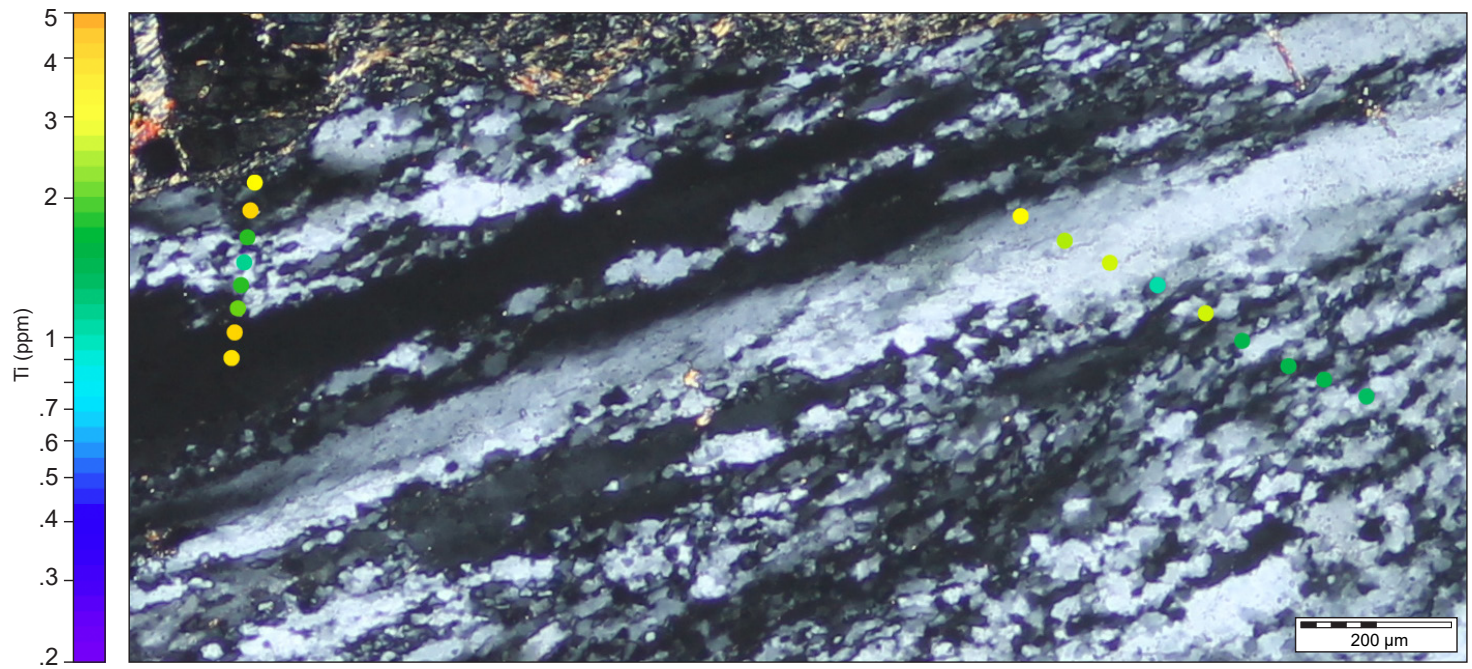

Figure 3. Cross polarized image showing dynamically recrystallized quartz in an ultramylonite sample (77912). Large ribbon grains, showing undulose extinction and subgrains, are interpreted as remnants, predating ultramylonite deformation. Recrystallized zones contain small, more equant grains with relatively uniform extinction. Typical of samples found within $\sim 150 \mathrm{~m}$ of the Alpine Fault, lower Ti concentrations (green dots) are found in recrystallized zones than in the ribbon grains (yellow and orange dots).

\subsection{Mylonites and ultramylonites}

Towards the Alpine Fault the mineral phases in the quartzofeldspathic mylonites and ultramylonites become more mixed and grain size (all grains, i.e., recrystallized plus inherited grains) decreases. $S$ - $C$ and $C^{\prime}$ fabrics are abundant. Minor chlorite is present in some rocks but is less abundant than in the protomylonites. Within a few hundred meters of the Alpine Fault, phase mixing is pronounced, particularly in ultramylonite layers, and domains of pure quartz are restricted to rare foliation-parallel veins and metachert layers. Quartz aggregates generally consist of slightly elongate (axial ratios mostly $>2: 1$ ) grains of size $40-100 \mu \mathrm{m}$. Except in the metacherts and deformed pure quartz veins, large quartz grains with undulose extinction are much rarer in the ultramylonites and mylonites than in the protomylonites. The maximum typical long axis of quartz grains in the mylonites is around $1 \mathrm{~mm}$ and decreases in size towards the fault. The larger quartz grains in the mylonites are bounded by interlobate high-angle boundaries, with only weak undulose extinction and occasional aggregates of subgrains. In mylonitic metachert samples, secondary phases are often encased in quartz, which often forms elongate, ribbon-like foliationparallel grains bounded by micas. These quartz grains display castellate microstructures, pinning, and other indicators of high-temperature grain boundary migration (Jessel, 1987; Little et al., 2015). Within $\sim 100 \mathrm{~m}$ of the fault, rare concentrations of quartz are often strongly recrystallized with a recrystallized grain size on the order of $10-20 \mu \mathrm{m}$. In these samples, ribbon grains are common and often filled with 10-20 $\mu \mathrm{m}$ subgrains (Fig. 3), suggesting subgrain rotation recrystallization was a dominant process (Hirth and Tullis, 1992; Stipp et al., 2002).

\section{Cathodoluminescence}

CL intensity generally correlates with $\mathrm{Ti}$ concentration such that bright CL corresponds with high $\mathrm{Ti}$ concentrations (Wark and Spear, 2005), and several studies have utilized the panchromatic CL signal as a proxy for Ti concentrations (Spear et al., 2012; Bestmann and Pennacchioni, 2015; Nevitt et al., 2017). Typical CL images of the Alpine Fault mylonites and protomylonites show a homogeneous illumination (e.g., Fig. 4a), generally with a thin dark rim around the edges of grains (note that this relationship is reversed in the hyperspectral CL images in Fig. 4a and b that show brighter rims). Rare samples contain grains with gradients in CL, typically large grains with higher CL that diminishes gradually towards grain edges. In these cases, Ti concentrations are generally correlated with panchromatic CL; however, several exceptions to this pattern were noted. The typical association of recrystallized grains with darker CL and low Ti (e.g., Kidder et al., 2013) was rarely observed in the mylonites and protomylonites but is common in the ultramylonites. The sample analyzed using hyperspectral CL has a homogeneous Ti concentration, so the typical association of blue light intensity and higher Ti (Wark and Spear, 2005) was not observed, and instead variation in the blue wavelength signal is seen to be a function of grain orientation (Fig. 4). We note that both these anomalous results and those of Kidder et al. (2013), who found a brighter blue CL signal in recrystallized areas, were observed in quartz with Ti concentrations 

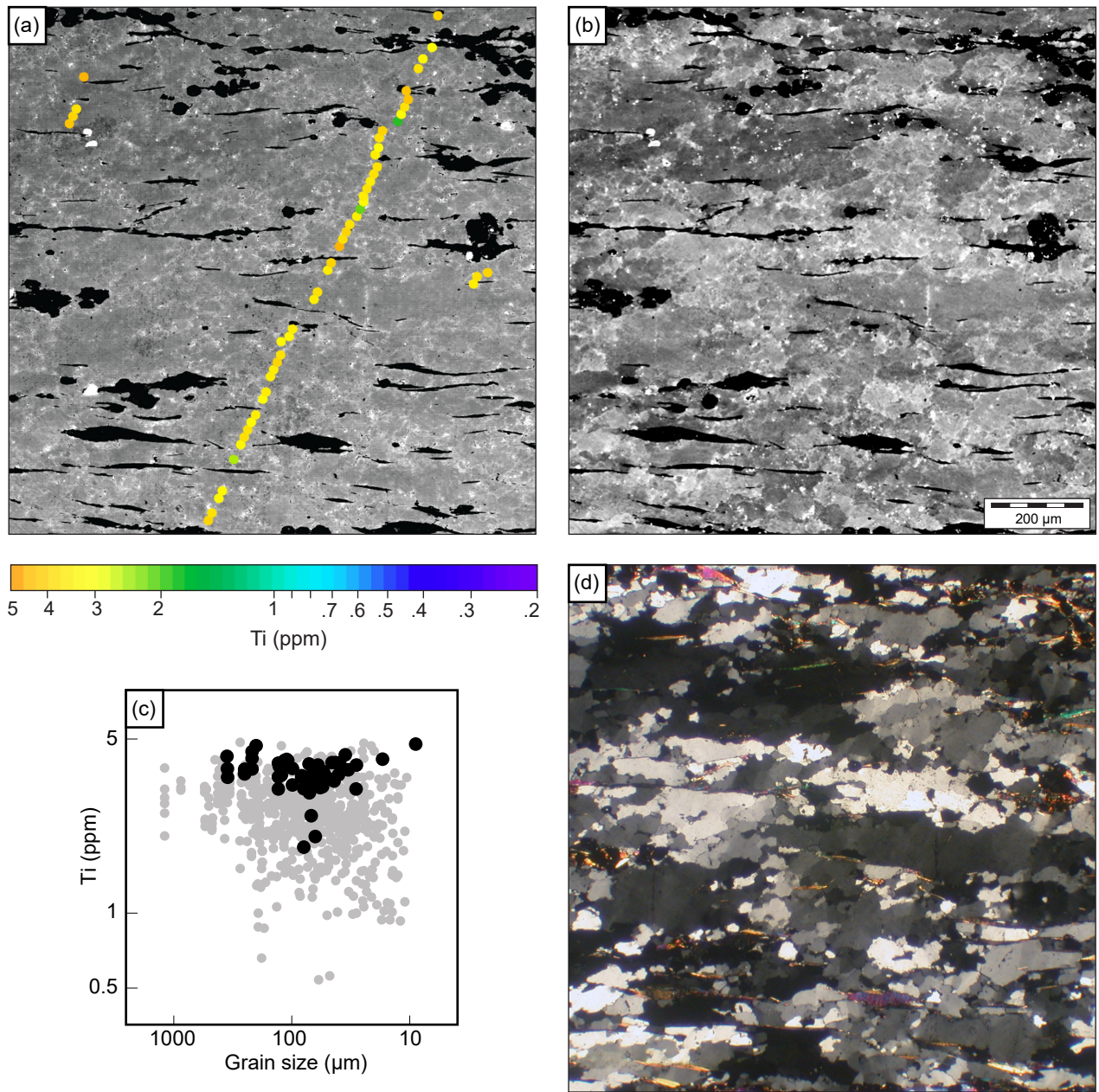

Figure 4. (a) Panchromatic (200-960 nm) cathodoluminescence (CL) image of protomylonite metachert sample 77900 showing uniformity of Ti concentrations at analysis points. Panel (b) shows $470 \mathrm{~nm}$ wavelength CL image. (c) Ti-in-quartz data for this sample (black) against a backdrop of data from other Gaunt Creek samples - no variation in Ti content with grain size is observed. (d) Cross-polarized photomicrograph of the same area. As typical of many samples, Ti-in-quartz contents vary between $\sim 2$ and 3 ppm, with no apparent spatial pattern. The blue spectrum peak $(\sim 470 \mathrm{~nm}, 2.65 \mathrm{eV})$ is dependent on quartz $c$-axis orientation, since dark grains in panel (b) are also dark in panel (d). The Ti peak at $\sim 415 \mathrm{~nm}$ (Wark and Spear, 2005) was not detected in this sample, probably due to the low concentrations of Ti in the sample.

much lower than typically measured (e.g., Wark and Spear, 2005).

\section{Ti-in-quartz concentrations: observations}

\subsection{General observations}

The bulk composition of Alpine Schist samples does not appear to be a significant factor controlling the Ti concentration in their quartz grains. Neighboring felsic and mafic schists have ranges of Ti concentration that broadly overlap, although a few amphibolite and metachert samples have up to $\sim 1 \mathrm{ppm}$ higher Ti concentrations than nearby quartzofeldspathic schists (Fig. 5). The presence of chlorite and rutile in samples (Table 1) is also not systematically associated with higher or lower Ti concentrations. In samples containing rutile, its abundance relative to other oxides varies from about $2 \%$ to $97 \%$, but these values are not correlated with average Ti-in-quartz concentrations of the samples.

The range of $\mathrm{Ti}$ values increases with decreasing grain size (Fig. 6) (c.f. Kidder et al., 2013). Grains larger than $\sim 200 \mu \mathrm{m}$ in the two creeks have indistinguishable Ti concentrations, but smaller grains in two samples from Stony Creek (including one from Cross et al., 2015) have lower Ti values than observed in Gaunt Creek (Fig. 6). Figure 7 plots Ti concentration versus distance to grain boundaries (Fig. 7a) and distance to any dark mineral likely to contain $\mathrm{Ti}$ as a major component such as biotite, hornblende, ilmenite, magnetite, or rutile (Fig. 7b). Ti concentrations have values of 2-4 ppm Ti for nearly all analyses further than $50 \mu \mathrm{m}$ from grain edges, whereas lower values gradually become more 
Table 1. Information on individual samples. All samples are from Gaunt Creek with the exception of Stony Creek sample ST-12c_iv. GPS data use the New Zealand Transverse Mercator Projection 2000. Distances are estimated structural distances measured perpendicular to foliation. Rutile and chlorite columns indicate whether these minerals were observed ("y") or not ("n"). Samples identified by numbers 77*** are archived in the Otago University collection; qfs: quartzofeldspathic.

\begin{tabular}{|c|c|c|c|c|c|c|c|}
\hline Sample & Northing & Easting & Distance (m) & Composition & Structure type & Rutile & Chlorite \\
\hline 77921 & 5200537 & 1382891 & 83 & qfs & mylonite & $\mathrm{y}$ & $\mathrm{n}$ \\
\hline 77911 & 5200537 & 1382891 & 118 & qfs & mylonite & $\mathrm{n}$ & $\mathrm{n}$ \\
\hline 77920 & 5200511 & 1383128 & 133 & mafic part & mylonite & $\mathrm{y}$ & trace \\
\hline 77920 & 5200511 & 1383128 & 133 & chert part & mylonite & $\mathrm{y}$ & trace \\
\hline 77821 & 5200508 & 1382904 & 140 & qfs/mafic & ultramylonite & $\mathrm{y}$ & $\mathrm{y}$ \\
\hline 77913 & 5200511 & 1382888 & 137 & chert & mylonite & $\mathrm{y}$ & $\mathrm{y}$ \\
\hline 77915 & 5200511 & 1382888 & 137 & mafic part & mylonite & $\mathrm{y}$ & $\mathrm{y}$ \\
\hline 77915 & 5200511 & 1382888 & 137 & vein in mafic & mylonite & $\mathrm{y}$ & $\mathrm{n}$ \\
\hline 77923 & 5200516 & 1383157 & 149 & mafic part & mylonite & $\mathrm{y}$ & $\mathrm{y}$ \\
\hline 77923 & 5200516 & 1383157 & 149 & chert part & mylonite & $\mathrm{y}$ & $\mathrm{n}$ \\
\hline 77912 & 5200551 & 1382908 & 159 & augen mafic feldspar & ultramylonite & $\mathrm{n}$ & $\mathrm{y}$ \\
\hline 77925 & 5200564 & 1383283 & 246 & qfs & mylonite & $\mathrm{y}$ & $\mathrm{n}$ \\
\hline 77925 & 5200564 & 1383283 & 246 & vein in qfs & mylonite & $\mathrm{y}$ & in late vein \\
\hline 77886 & 5200429 & 1383283 & 292 & qfs & mylonite/proto & $\mathrm{y}$ & $\mathrm{y}$ \\
\hline 77887 & 5200426 & 1383287 & 293 & mafic part & mylonite & $\mathrm{n}$ & $\mathrm{n}$ \\
\hline 77887 & 5200426 & 1383287 & 293 & chert part & mylonite & $\mathrm{y}$ & $\mathrm{y}$ \\
\hline 77900 & 5200409 & 1383570 & 461 & chert & schist & $\mathrm{y}$ & $\mathrm{n}$ \\
\hline 5.2 .1 .13 & 5200409 & 1383570 & 461 & qfs & proto & $\mathrm{n}$ & $\mathrm{n}$ \\
\hline 5.26 .1 .18 & 5200409 & 1383570 & 461 & qfs & proto & $\mathrm{n}$ & $\mathrm{n}$ \\
\hline 77930 & 5200362 & 1383619 & 515 & mafic & proto & $\mathrm{n}$ & $\mathrm{y}$ \\
\hline 77932 & 5200344 & 1383638 & 541 & mafic part & proto & $\mathrm{y}$ & $\mathrm{n}$ \\
\hline 77932 & 5200344 & 1383638 & 541 & chert part & proto & $\mathrm{y}$ & $\mathrm{n}$ \\
\hline 05.2 .1 .11 & 5200344 & 1383638 & 541 & qfs & proto & $\mathrm{n}$ & $\mathrm{y}$ \\
\hline 05.2 .1 .11 & 5200344 & 1383638 & 541 & vein in qfs & proto & $\mathrm{n}$ & $\mathrm{n}$ \\
\hline 77878 & 5200202 & 1383798 & 741 & qfs & proto/schist & $\mathrm{y}$ & $\mathrm{y}$ \\
\hline ST-12c_iv & 5193839 & 1374804 & 800 & qfs & proto & $\mathrm{n}$ & $\mathrm{y}$ \\
\hline 77875 & 5200152 & 1383943 & 869 & qfs & proto/schist & $\mathrm{n}$ & in vein \\
\hline 77982 & 5200115 & 1384037 & 942 & qfs & schist & $\mathrm{y}$ & $\mathrm{n}$ \\
\hline 77980 & 5200163 & 1384269 & 1090 & qfs & schist & $\mathrm{y}$ & $\mathrm{y}$ \\
\hline
\end{tabular}

common closer to grain boundaries. The low frequency of Ti values $<1 \mathrm{ppm} \mathrm{Ti}$ at distances from grain boundaries $<5 \mu \mathrm{m}$ may be a function of minor contamination along grain boundaries (Fig. 7a). The potential effect of proximity to minerals containing non-trace amounts of Ti (mainly biotite and $\mathrm{Fe}-\mathrm{Ti}$ oxide) appears to be minimal (Fig. 7b). The lowest $\mathrm{Ti}$ quartz grains $(\mathrm{Ti}<0.8 \mathrm{ppm})$ were only found $>50 \mu \mathrm{m}$ from Ti-bearing phases (Fig. 7b). In one metachert sample (77913), a transect away from a large rutile grain showed no variation in Ti with distance from the grain.

\subsection{Observations: schists, protomylonites, and mylonites}

Because high-temperature dynamic recrystallization can involve resetting of $\mathrm{Ti}$ contents as grain boundaries sweep through quartz (e.g., Grujic et al., 2011), it is nontrivial to ascertain whether the limited range of $2-4 \mathrm{ppm}$ Ti in grains coarser than $\sim 250 \mu \mathrm{m}$ (Fig. 6) indicates initial Ti concentrations prior to Alpine Fault motion or whether they were reset by prolonged high-temperature deformation. Most quartzrich layers have relatively homogeneous $\mathrm{Ti}$ concentrations (Fig. 4) as commonly observed in samples that experienced protracted high-temperature metamorphism (e.g., Spear and Wark, 2009).

In the Gaunt Creek mylonites and protomylonites, recrystallized grains of all sizes generally have Ti contents that are also in the same $2-4 \mathrm{ppm}$ range as the coarser grains, although some moderate-sized $(20-200 \mu \mathrm{m})$ grains with $\mathrm{Ti}$ concentrations in the range $1-2 \mathrm{ppm}$ are also present (Fig. 8). In individual samples, Ti concentrations are often homogeneous, varying with no systematic spatial pattern between about 2 and 4 ppm (e.g., Fig. 4). Some samples do contain local, minor but systematic variations in Ti within this range of values; however, no overarching pattern was observed. For example, in sample 77886, Ti increases from $\sim 2.5$ to $3.5 \mathrm{ppm}$ where a quartz layer is pinched, recrystallized, and finer-grained adjacent to a garnet porphyroclast. Quartz in a similar microstructural setting was not associated with a 


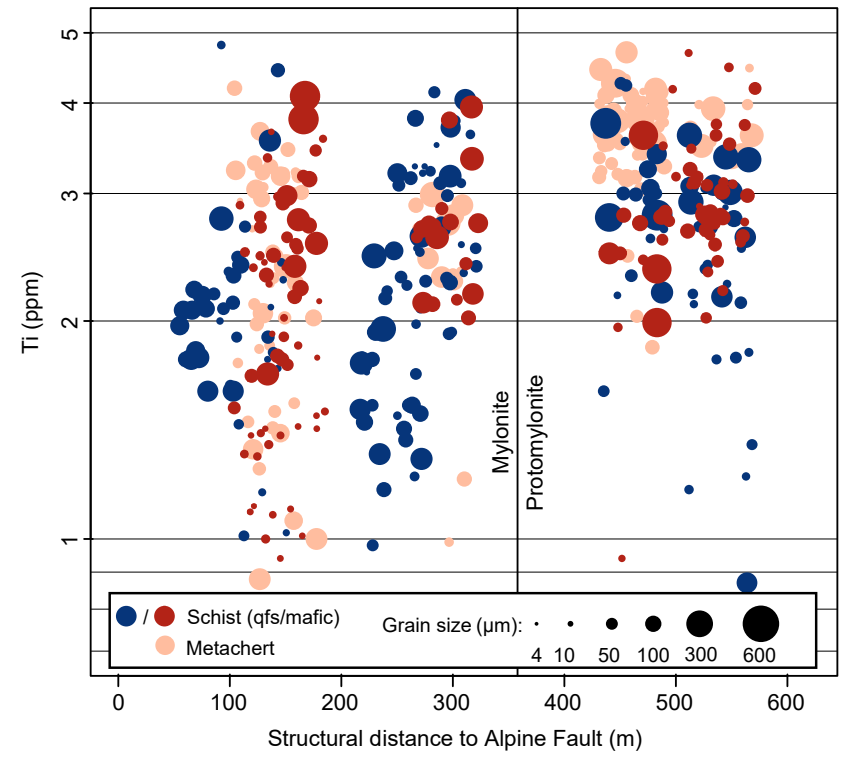

Figure 5. Ti concentrations vs. distance to the Alpine Fault, with analyses colored as a function of sample composition. With the exception of two protomylonite metachert samples with high $\mathrm{Ti}$ (at $\sim 450$ and $550 \mathrm{~m}$ ), no systematic effect of composition is evident. Samples at structural distances $>600 \mathrm{~m}$ are not plotted because they are uniformly quartzofeldspathic (qfs). The data are jittered along the $x$ axis by an amount not exceeding $30 \mathrm{~km}$ in order to increase the visibility of the data.

consistent change in $\mathrm{Ti}$ in the Alpine Fault rocks studied by Cross et al. (2015). Two metachert samples (77920 and 77923) contain $400 \mu \mathrm{m}$ thick quartz layers with low-Ti central areas in the range $1-2.5 \mathrm{ppm}$ Ti that increase to $\sim 3 \mathrm{ppm}$ at their edges. A similar pattern is observed in protomylonite sample 77982 and could be interpreted as indicating lower initial Ti values than $2-4 \mathrm{ppm}$ for these rocks. Several large quartz grains in sample 77982 also have bright-CL cores suggesting different "initial" Ti between the metachert and quartzofeldspathic portions of the sample. At a larger scale, there is a gradual decrease in average Ti concentrations of 3$4 \mathrm{ppm}$ at structural distances of $500 \mathrm{~m}$ from the Alpine Fault to values closer to $2-3 \mathrm{ppm}$ at $1100 \mathrm{~m}$ (Fig. 9). This pattern is particularly evident in coarse grains (Fig. 9 inset).

Two samples, a protomylonite and a mylonite $(77875$ and 77925), contain late, chlorite-bearing quartz veins that cut foliation. Quartz in both veins shows evidence of minor dynamic recrystallization and has Ti concentrations of 2-4 ppm. Given the high shear strains experienced by the Alpine Fault mylonites (Norris and Cooper, 2003), these latestage veins formed during the last few percent of penetrative mylonitic strain. The presence of chlorite in these veins constrains their emplacement temperatures and therefore the cessation of mylonitization to within the chlorite stability field, a wide temperature range from 360 to $500{ }^{\circ} \mathrm{C}$ in Alpine Fault rocks (Vry et al., 2007; Beyssac et al., 2016).

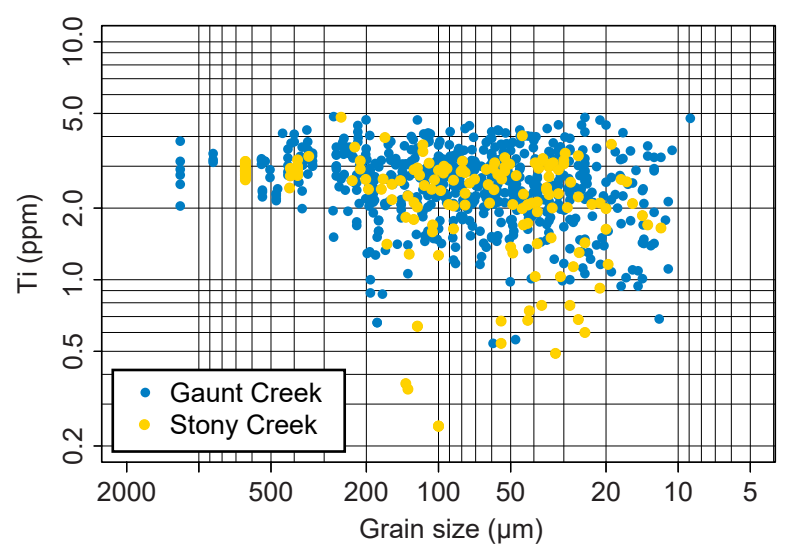

Figure 6. Plot of $\mathrm{Ti}$ concentration vs. grain size for all data. Grains $>250 \mu \mathrm{m}$ have a relatively homogeneous Ti concentration $\sim 2-4$ ppm, which we interpret to predate Alpine Fault deformation. Smaller grains $(<200 \mu \mathrm{m})$ were at least partly formed by dynamic recrystallization during late stages of deformation, exhumation, and cooling. Despite very large strains $(\gamma=12-120)$ at high temperature, less than half of the small recrystallized grains have Ti concentrations significantly lower than relict values of 2-4 ppm. We interpret that most deformation was associated with pressuretemperature conditions where $\mathrm{Ti}$ concentrations of $2-4 \mathrm{ppm}$ were stable, specifically that mylonite and protomylonite deformation occurred along a cooling path that followed a constant-Ti isopleth (see text for details). Stony Creek analyses include data from Cross et al. (2015).

Fine recrystallized quartz in two of three $C^{\prime}$ type shear bands shows evidence of lower Ti-in-quartz concentrations than surrounding quartz. A $C^{\prime}$ shear band from a Stony Creek sample (same as sample ST_12 in Little et al., 2016) shows a marked decrease in $\mathrm{Ti}$ concentrations within the shear band (Fig. 10). In Gaunt Creek, quartz in one $C^{\prime}$ band from near the mylonite-protomylonite boundary (77886) shows a lower Ti content $(\sim 2.25 \mathrm{ppm})$ than quartz in the foliation that is crosscut $(\sim 3.5 \mathrm{ppm} \mathrm{Ti})$. A shear band in protomylonite sample 5.2.1.13, however, shows little to no decrease in $\mathrm{Ti}$ in a (chlorite-absent) $C^{\prime}$ band.

\subsection{Observations: ultramylonites}

The population of quartz grains in ultramylonites of size $>30 \mu \mathrm{m}$ generally have indistinguishable, or slightly lower, Ti concentration when compared to rocks further from the fault (Fig. 8). Finer grains, however, are distinctly shifted to lower values (1-2.5 ppm vs. values of 2-4 ppm in the mylonites and protomylonites). This trend is associated with a decrease in average quartz grain size and a deviation from the higher Ti concentrations in adjacent coarser grains (Fig. 9). This pattern is evident in individual transects from coarsergrained areas to finer-recrystallized areas with decreased $\mathrm{Ti}$ concentrations of 1-2 ppm in both ultramylonite samples as 

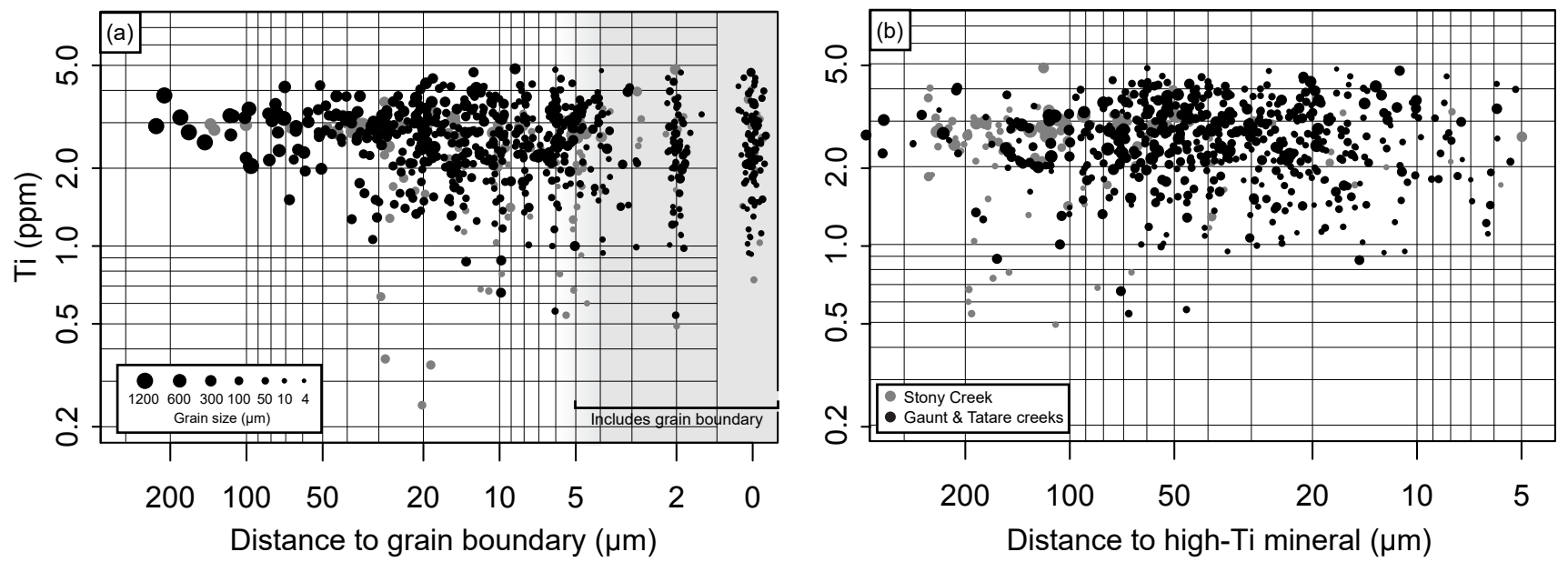

Figure 7. Ti concentrations in quartz vs. the distance (in thin-section plane) from the analysis center to the nearest (a) grain boundary (of any type) or (b) dark mineral that might act as a potential Ti source or sink such as biotite or Fe-Ti oxide. The increased presence of low Ti concentrations closer to grain boundaries (a) results from recrystallization and diffusion during deformation at decreasing temperatures. The lack of a clear trend in panel (b) suggests that Ti-in-quartz concentrations were not strongly affected by proximity to neighboring Ti-rich phases and that diffusion of Ti along grain boundaries was not a limiting factor in Ti-in-quartz concentrations. Data from Cross et al. (2015) are plotted in panel (a) but are not available for panel (b). The data are jittered along the $x$ axis in order to increase visibility.

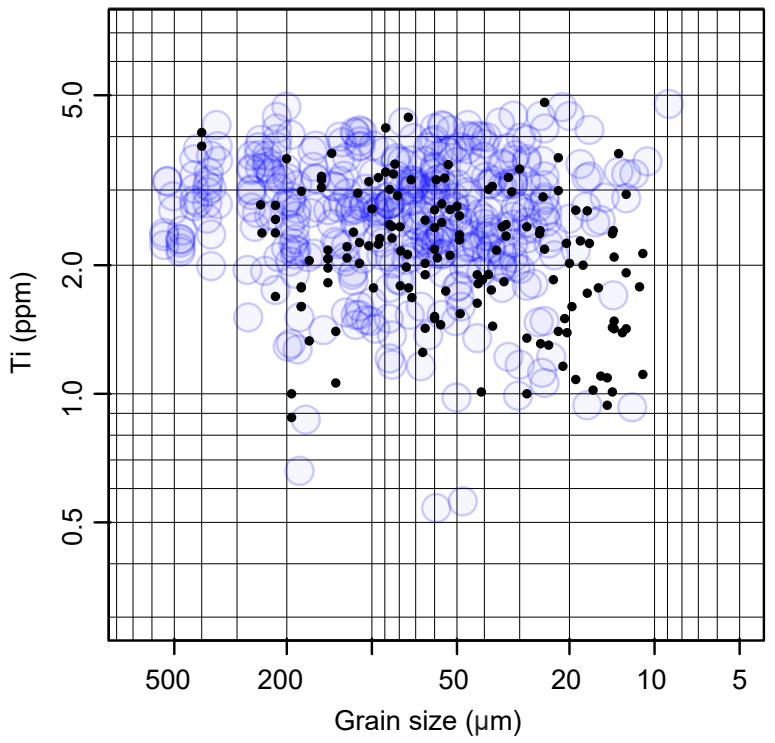

Figure 8. Ti vs. grain size for Gaunt Creek samples. Samples at structural distances $<160 \mathrm{~m}$ from the fault are shown in black (mainly ultramylonites), while mylonites and protomylonites are plotted in transparent blue. The trend in the samples close to the fault suggests that late recrystallization (as indicated by finer grain size) occurred at conditions where lower concentrations of $\mathrm{Ti}$ were stable. Only partial equilibration of Ti-in-quartz values was achieved during recrystallization of fine grains in the ultramylonite. Away from the fault there is no general trend of fine grains having lower Ti concentrations. well as the closest mylonite sample (77911) to the fault (e.g., Fig. 3).

\section{Discussion}

\subsection{Evolution of Ti concentrations}

\subsubsection{Initial Ti-in-quartz concentrations were $2-4$ ppm}

Coarse polygonal quartz grains in non-mylonitic schist outside the present study area are inferred to have formed in the Mesozoic during an extended, non-orogenic period when the rocks resided at high temperature in the middle to lower crust (Little, 2004), i.e., prior to their Neogene exhumation resulting from shearing on the Alpine Fault. The roughly 30 coarse grains analyzed $(>250 \mu \mathrm{m})$ from schist and mylonite samples in our study contain a restricted range of $\mathrm{Ti}$ concentrations of 2-4 ppm (Fig. 6), and given their large size (some $>1 \mathrm{~mm}$ ), we also infer these to be Mesozoic grains. The characteristic diffusion timescale (e.g., Spear, 1995) for $250 \mu \mathrm{m}$ grains using the experimental data of Cherniak et al. (2007) at a peak Alpine Fault mylonitization temperature of $\sim 550^{\circ} \mathrm{C}$ (Toy et al., 2010; Cross et al., 2015) is $1.5 \mathrm{Ga}$, seemingly barring the possibility that these grains were reset by diffusional processes during mylonitization lasting a few million years in the Neogene. We interpret that the 2 $4 \mathrm{ppm}$ Ti-in-quartz concentrations in large grains were stabilized during Mesozoic metamorphism, prior to Neogene Alpine Fault-related deformation.

The significance of the apparent trend in Ti concentrations of the largest grains in the Gaunt Creek section towards 


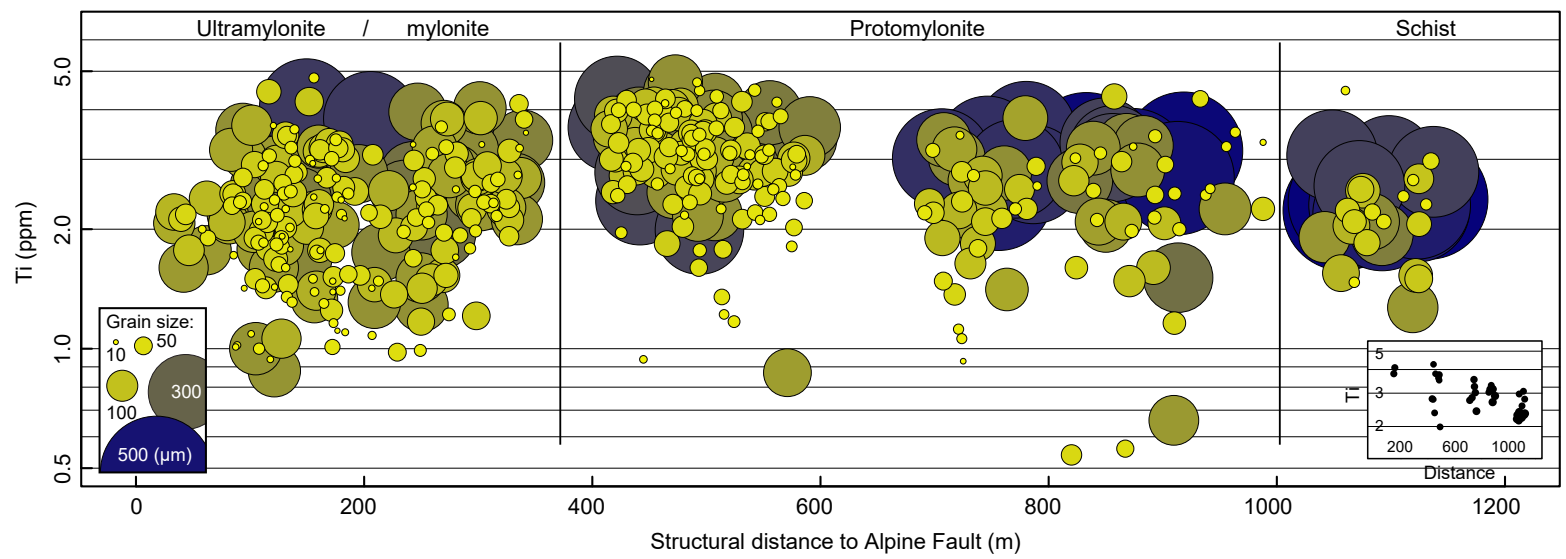

Figure 9. Ti concentrations vs. distance from the Alpine Fault for Gaunt Creek samples, with dot size indicating grain size. Small recrystallized grains $(<\sim 300 \mu \mathrm{m})$ near the fault are more likely to show decreased Ti concentrations than similar sized recrystallized grains away from the fault - this supports microstructural observations (e.g., Fig. 3) that lower Ti concentrations were stable during ultramylonite deformation but not during mylonite and protomylonite deformation. Inset shows that Ti concentration in the coarsest grains $(>300 \mu \mathrm{m})$ increases slightly towards the fault. The data are jittered along the $x$ axis by an amount not exceeding $50 \mathrm{~km}$ in order to increase visibility.

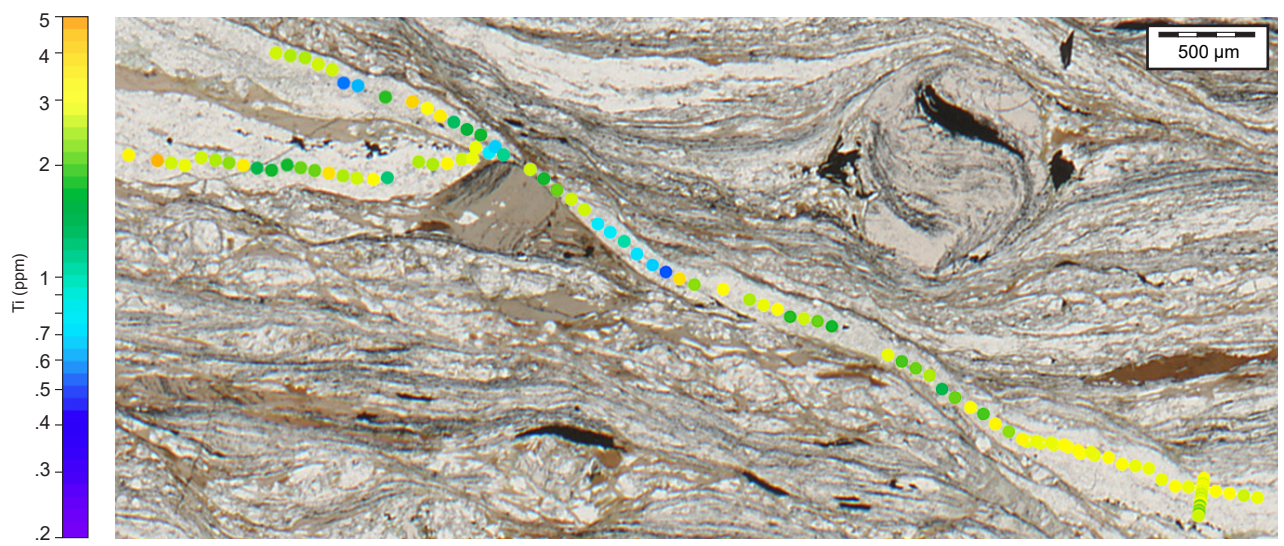

Figure 10. Photomicrograph of an older foliation (near-horizontal in this image) cut by a $C^{\prime}$ shear band in a sample from Stony Creek. Ti concentrations are plotted from both inside and outside the shear band. Most of the lowest Ti measurements are from within the shear band, indicating some loss of $\mathrm{Ti}$ in quartz recrystallized during formation of the $C^{\prime}$ layer. The foliations preserved in the garnet (upper right) and large biotite grain predate Alpine Fault deformation.

higher Ti concentrations at deeper structural levels (Fig. 9 inset) is unclear. If the variation in initial Ti concentration were purely the result of differences in initial depth along a vertical column of rock, the position of the isopleths in Fig. 11 would indicate a stretch perpendicular to foliation of one-seventh, more than twice the foliation-perpendicular component estimated in previous studies (Holm et al., 1989; Holcombe and Little, 2001; Toy et al., 2013). It is worth noting, however, that because of the extreme simple shear strains experienced by the Alpine Fault mylonites, the various hanging wall rocks sampled for this study and presently separated by distances $<1 \mathrm{~km}$ were originally separated by $>100 \mathrm{~km}$ (Norris and Cooper, 2003). Given these large offsets, it is possible that the large apparent shortening was a function of pre-Alpine Fault regional variations in geothermal gradient (i.e., a re- gional variability in initial Ti concentration at a given depth) and/or shallowing of the hypothesized deep, semi-horizontal continuation of the Alpine Fault towards the east (Batt and Braun, 1997; Little et al., 2002a; Cox and Sutherland, 2007).

\subsubsection{Protomylonite and mylonite deformation occurred along a geothermal gradient of $5^{\circ} \mathrm{C} \mathrm{km}^{-1}$}

Two observations support a hypothesis that the pre-Alpine Fault 2-4 ppm range of Ti-in-quartz concentrations was stable for nearly the entire period of protomylonite and mylonite deformation. First, slightly deformed chlorite-bearing quartz veins that crosscut foliation also have Ti concentrations of 2-4 ppm. Second, small quartz grains generated in the my- 


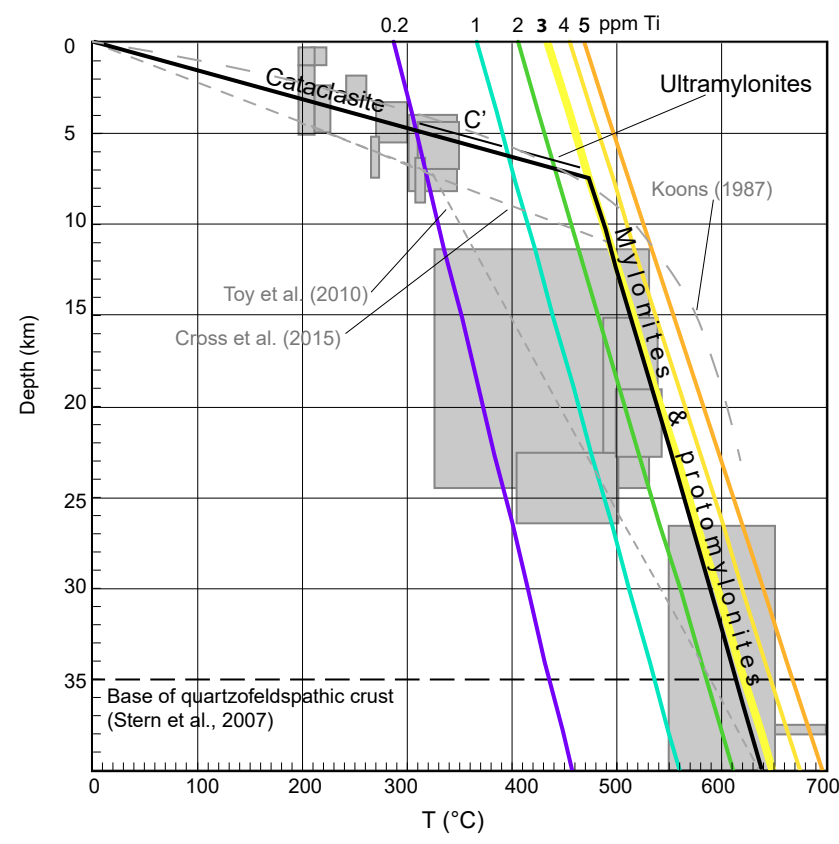

Figure 11. Temperature-depth diagram showing constraints on the Alpine Fault geothermal gradient from previous studies (grey boxes), proposed and previously proposed geothermal gradients (solid black and dashed lines, respectively), and experimentally determined constant-Ti contours (colored isopleths) covering the range of observed Ti-in-quartz concentrations. A Ti activity of 0.1 (Thomas et al., 2010) and crustal density of $2.7 \mathrm{~g} \mathrm{~cm}^{-3}$ are used to plot the isopleths. Ti activity is constrained by the fact that activities larger than 0.1 would shift the isopleths to the left and require quartz recrystallization at unrealistically low quartz recrystallization temperatures $\left(<300^{\circ} \mathrm{C}\right)$. Previous temperature-pressure constraints are from Craw (1997), Holm et al. (1989), Green (1992), Grapes (1995), Cooper (1980), and Vry et al. (2004) as summarized by Toy et al. (2010).

lonites and protomylonites during Alpine Fault deformation contain similar concentrations of $\mathrm{Ti}$ as coarser grains (e.g., Figs. 4, 8). This is atypical behavior, since increasingly finer grains formed during exhumation generally show systematic changes in Ti concentration (e.g., Kohn and Northrup, 2009; Behr and Platt, 2011; Kidder et al., 2013; the Alpine Fault ultramylonites described in this paper). We suggest that, as commonly observed, gradually increasing stresses due to strengthening during cooling also led to an increasingly fine-grained overprint during exhumation of the Alpine Fault mylonites. The unvarying Ti-in-quartz concentrations in the Alpine Fault can be explained, then, if the exhumation path happened to coincide with a contour of constant-Ti concentration in pressure-temperature space (an "isopleth", Fig. 11). The isopleths plotted in Fig. 11 are based on the experimental results of Thomas et al. (2010) and correspond to a slope of $5^{\circ} \mathrm{C} \mathrm{km}^{-1}$, a plausible value that is identical to the deep geothermal gradient proposed by Cross et al. (2015) based on different criteria. Thus, despite a significant de- crease in temperature, Ti levels of $2-4 \mathrm{ppm}$ remained stable during the bulk of Alpine Fault mylonitization.

\subsubsection{Ultramylonite deformation involved a decrease in stable Ti levels to 1-2 ppm}

In the ultramylonites, Ti-in-quartz concentrations in grains coarser than $50 \mu \mathrm{m}$ are generally indistinguishable from those in protomylonites and mylonites; however, lower Ti concentrations (1-2 ppm) are much more common in fine recrystallized grains in the ultramylonites (Fig. 8). We interpret the clustering of Ti-in-quartz values in the range 1-2 ppm in the recrystallized areas of several ultramylonite samples as indicating the equilibrium concentration associated with the latest phase of quartz recrystallization near the Alpine Fault. Note that the spread of Ti-in-quartz concentrations in fine grains generated during late recrystallization (Figs. 8, 9, 10) suggests that dynamic recrystallization was not $100 \%$ effective in shifting $\mathrm{Ti}$ concentrations to equilibrium values, as observed elsewhere (e.g., Haertle et al., 2013; Kidder et al., 2013; Bestmann and Pennacchioni, 2015; Nevitt et al., 2017).

\subsubsection{Latest deformation involving quartz recrystallization occurred off-fault}

The lowest $\mathrm{Ti}$ concentrations measured in this study $(0.5-$ $0.8 \mathrm{ppm}$ ) come from within a chlorite-bearing $C^{\prime}$ shear band in a protomylonite sample from Stony Creek (Fig. 10). $C^{\prime}$ shear bands are abundant in Alpine Fault protomylonites (Little et al., 2016) and elsewhere and are widely understood to be late deformation features (e.g., Toy et al., 2012) accommodating minor amounts of strain relative to the total mylonitic deformation (Gillam et al., 2013). The low Ti-inquartz concentrations in this shear band, as well as the decreased $\mathrm{Ti}$ concentrations in one of two Gaunt Creek shear bands analyzed, are consistent with partial resetting during a late stage of low-temperature deformation.

The Stony Creek mylonite sample analyzed by Cross et al. (2015) contains very low Ti concentrations (0.2-0.4 ppm) in relatively large grains (up to $130 \mu \mathrm{m}$ ) not microstructurally associated with any obvious late deformation phase. Thus, at face value, the very last quartz grains to recrystallize were not in localized $C^{\prime}$ zones but were instead fairly moderate-sized quartz grains not associated with shear bands or another type of microstructure indicative of late, low-temperature deformation. Anomalously low Ti concentrations were also observed locally in Gaunt Creek, but the $\mathrm{Ti}$ values are not as low (0.5-1 ppm; Fig. 6). It is unclear if these observations are influenced by some difference between Stony and Gaunt creeks, but it is noteworthy that the two samples from Stony Creek have the lowest Ti-in-quartz measurements observed. Possibly deformation in Stony Creek continued at lower temperatures than in Gaunt Creek (11 km to the NE), or there was a difference in the geothermal gradient between the two creeks. The two creeks show at least one composi- 
tional difference (more metacherts in Stony creek), so it is also possible that some systematic compositional differences might have reduced activity of $\mathrm{TiO}_{2}$ in Stony Creek. If differences in bulk composition between the two creeks were the cause, however, we would not expect coarse grains in the two creeks to have indistinguishable Ti concentrations (Fig. 6) nor would we expect an absence of a compositional effect locally in Gaunt Creek samples (Fig. 5).

In any case, the presence of Ti concentrations $<0.8 \mathrm{ppm}$ along $C^{\prime}$ shear bands and elsewhere in the protomylonite zone and the absence of such values closer to the fault suggests that the latest phase of deformation involving dynamic recrystallization of quartz did not take place in the ultramylonites as might be expected based on general models of shear zones involving increased localization at shallower depths (e.g., Sibson, 1977). Instead, the latest phase of deformation involving quartz recrystallization occurred in a broad region of protomylonites and mylonites outside the fault core. Toy (2007) reached the same conclusion based on observation of a more retrograde mineral assemblage associated with $C^{\prime}$ shear bands. An explanation for this may be illustrated in strength-depth diagrams plotting flow laws at different strain rates (e.g., Kidder et al., 2012): near the brittle-ductile transition, deformation at slow strain rates will be in the plastic regime, while at the same pressuretemperature conditions, faster strain rates can be accommodated with less resistance by brittle mechanisms. We suggest that near the brittle-ductile transition, as strain rates increased in the narrow ( $<10 \mathrm{~m}$ wide) cataclastic zone, deformation away from this localized zone remained slow enough to favor some dislocation creep. Put differently, the brittleductile transition extended to deeper levels near the fault than away from it, as predicted in numerical models of the Alpine Fault by Ellis and Stöckhert (2004).

\subsection{Activity of $\mathrm{TiO}_{2}$}

The activity of $\mathrm{TiO}_{2}\left(a_{\mathrm{TiO}_{2}}\right)$ has proven to be a major source of uncertainty in previous studies (e.g., Grujic et al., 2011; Nevitt et al., 2017), apparently varying by nearly 1 order of magnitude in previous studies of quartzofeldspathic rocks from values as high as 1.0 (Kidder et al., 2013) to 0.2 (Grujic et al., 2011). The lack of knowledge of $a_{\mathrm{TiO}_{2}}$ and the factors that control it complicates a quantitative estimation of temperature using the TitaniQ thermobarometer. Establishing $\mathrm{Ti}$ activities in natural samples is also hindered by competing calibrations of TitaniQ (Thomas et al., 2010, 2015; Huang and Audétat, 2012). While we employ the calibration of Thomas et al. $(2010,2015)$, we note that using the Huang and Audétat (2012) calibration would not substantially change our results (apart from the estimated $a_{\mathrm{TiO}_{2}}$ ) because the two calibrations have similar slopes in pressuretemperature space at pressures $>2$ kbar (see Fig. 6 of Kidder et al., 2013).
Despite these uncertainties, sufficient independent information is available for Alpine Fault rocks to constrain their $a_{\mathrm{TiO}_{2}}$ to a very low value of 0.1 (using the Thomas et al., 2010 calibration). This value is estimated assuming that the lowest observed Alpine Fault Ti-in-quartz concentrations of $\sim$ $0.2 \mathrm{ppm}$ represent deformation at the low-temperature limit for dynamic recrystallization of quartz of $300^{\circ} \mathrm{C}$ (Dresen et al., 1997; Dunlap et al., 1997; Stöckhert et al., 1999; van Daalen et al., 1999; Stipp et al., 2002) and using the relatively steep $\left(>50^{\circ} \mathrm{C} \mathrm{km}^{-1}\right.$ ) upper-crustal geothermal gradient indicated by fluid inclusions (e.g., Toy et al., 2010) (Fig. 11) and borehole data in the vicinity of the study area (Sutherland et al., 2012, 2017). The lower limit of $0.2 \mathrm{ppm}$ Ti has also been observed in Alpine Fault rocks to the south near the Haast River (Kidder et al., 2016a). Using a higher $a_{\mathrm{TiO}_{2}}$ would require that recrystallization of quartz took place at unrealistically low temperatures (Fig. 11). An activity of $\mathrm{TiO}_{2}$ of 0.1 also places the estimated initial Ti concentration of $\sim 3 \mathrm{ppm}$ at a temperature of $600{ }^{\circ} \mathrm{C}$ near the base of the crust, consistent with the thermobarometric constraints from Vry et al. (2004) that mylonitization began at around $600^{\circ} \mathrm{C}$ and $11 \mathrm{kbar}$. A similar analysis using the Ti-in-quartz calibration of Huang and Audétat (2012) would involve an activity of $\mathrm{TiO}_{2}$ in the range $0.5-0.8$ (e.g., as adopted by Cross et al., 2015).

While it is convenient to assign a single value of $a_{\mathrm{TiO}_{2}}$ to a suite of rocks such as our sample set - and the overall consistency of Ti-in-quartz concentrations in different lithologies generally supports this (Fig. 5) - sample-scale or microscale variations in $a_{\mathrm{TiO}_{2}}$ due to local differences in bulk or fluid composition may exist. Additionally, activity of $\mathrm{TiO}_{2}$ could also vary with temperature (Ashley and Law, 2015). An absence of Ti values of less than $\sim 1$ ppm at distances $<50 \mu \mathrm{m}$ from phases containing stoichiometric quantities of $\mathrm{Ti}$ (Fig. 7b) hints at both types of $a_{\mathrm{TiO}_{2}}$ variation. The absence of Ti values $<1 \mathrm{ppm}$ could be explained if $a_{\mathrm{TiO}_{2}}$ was higher than 0.1 in the vicinity of high-Ti minerals during the latest phase of quartz recrystallization. A change in $a_{\mathrm{TiO}_{2}}$ to a value of 0.5 in the immediate vicinity $(<50 \mu \mathrm{m})$ of Ti-bearing phases at temperatures of $300^{\circ} \mathrm{C}$ would stabilize Ti concentrations at $1 \mathrm{ppm}$ and explain the local absence of lower Ti measurements. The extent of recrystallization at these conditions was minor, as suggested by the low frequency of such analyses (Fig. 7) and their location only within $30 \mu \mathrm{m}$ of grain boundaries (Fig. 7a).

\subsection{Geothermal gradient of the Alpine Fault}

Considering that long-term average strain rates are wellestablished in the Alpine Fault mylonites at $\sim 10^{-12} \mathrm{~s}^{-1}$ (Norris and Cooper, 2003), we can place a rough estimate on the minimum temperature of mylonite deformation using a piezometer and flow law. The average recrystallized grain size in the Alpine Fault mylonites is in the range of 40-70 $\mu \mathrm{m}$ (Toy, 2007; Lindroos, 2013; Little et al., 2015), correspond- 
Phase 2. Geotherm $=60^{\circ} \mathrm{C} / \mathrm{km}$, rapid cooling
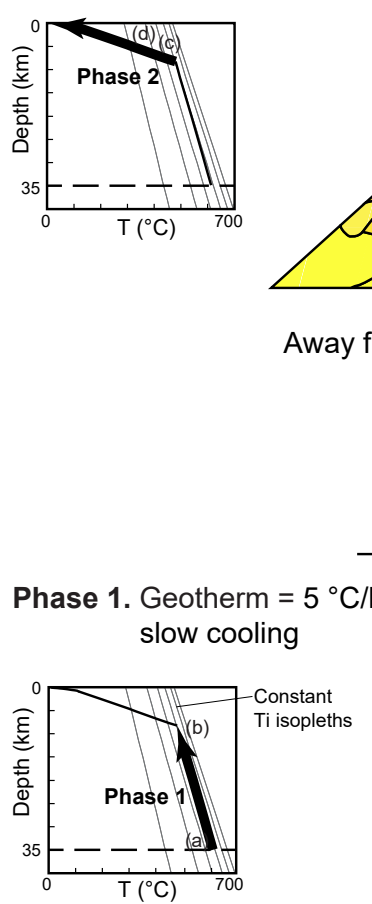

Phase 1. Geotherm $=5^{\circ} \mathrm{C} / \mathrm{km}$, slow cooling
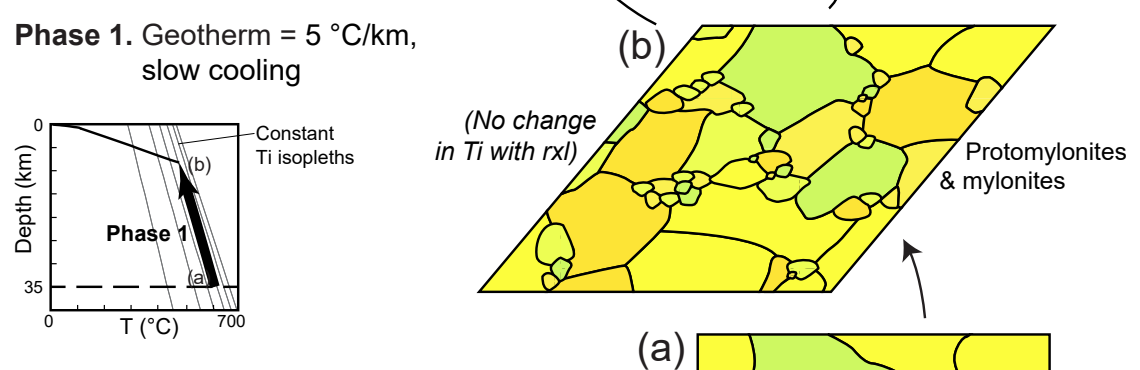

Limit of seismicity

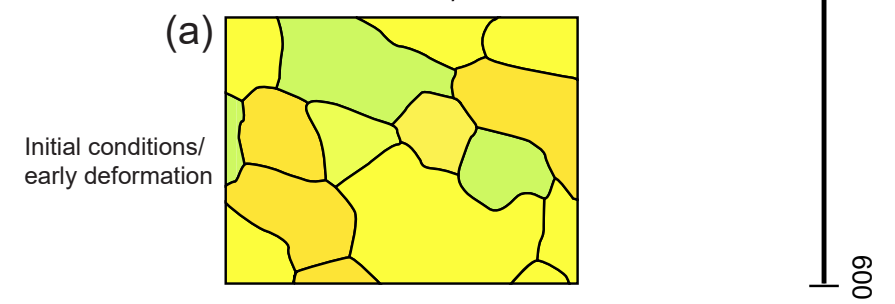

Figure 12. Simplified illustration of interpreted microstructural and Ti-in-quartz evolution. "Phase 1" deformation begins with Ti-in-quartz concentrations at 2-4 ppm (a). Strain associated with protomylonite and mylonite formation (b) involves recrystallization with no change in Ti-in-quartz concentrations due to exhumation along a constant-Ti isopleth (e.g., Fig. 11). During "phase 2," newly recrystallized quartz grains tend to have lower Ti concentrations as a result of cooling along a much steeper segment of the geothermal gradient (Fig. 11). Near the fault (c), ultramylonites form with Ti-in-quartz concentrations of 1-2 ppm. The latest quartz recrystallization occurs away from the fault in protomylonites and mylonites in $C^{\prime}$ bands (d). Sporadic recrystallization of some medium-sized grains with Ti-in-quartz concentrations below 2 ppm occurs in some rocks during phase 2 .

ing to stresses of 31-44 MPa (Cross et al., 2015) and a temperature of $430-480^{\circ} \mathrm{C}$ using the quartz flow law from Kidder et al. (2016b). The intersection of the $3 \mathrm{ppm}$ isotherm and this temperature range occurs at depths of $0-8 \mathrm{~km}$ (Fig. 11), thereby requiring an order of magnitude change in slope from about $5^{\circ} \mathrm{C} \mathrm{km}^{-1}$ to at least $60^{\circ} \mathrm{C} \mathrm{km}^{-1}$ at depths of $8 \mathrm{~km}$ or less. We adopt the values $\left(60^{\circ} \mathrm{C} \mathrm{km}^{-1}\right.$ above $\left.8 \mathrm{~km}\right)$ that minimize the magnitude of the kink, although shallower kinks and larger upper-crustal geothermal gradients would also fit the data presented here. This upper-crustal geothermal gradient falls close to the geothermal gradient of $63 \pm 2{ }^{\circ} \mathrm{C} \mathrm{km}^{-1}$ measured in the upper $140 \mathrm{~m}$ of the DFDP-1B borehole site at Gaunt Creek (Sutherland et al., 2012), although it is clear that there is considerable local variation in the upper-crustal geothermal gradient, likely due to fluid circulation associ- ated with topography (Sutherland et al., 2017). The Alpine Fault geothermal gradient predicted here is very similar to that presented by Cross et al. (2015) - differing only in the slightly shallower position of the kink at $480^{\circ} \mathrm{C}$ in this study (vs. $495^{\circ} \mathrm{C}$ ) and the correspondingly larger upper-crustal geothermal gradient in our analysis (Fig. 11). The general shape of a large upper-crustal geothermal gradient and low geothermal gradient at deeper levels was also predicted by early two-dimensional numerical models of Alpine Fault exhumation (Koons, 1987; Fig. 11), wherein rapid uplift leads to significant heat advection towards the surface followed by heat loss by conduction in a region of condensed near-surface isotherms. The position of the kink in this study also corresponds roughly to the maximum depth of earthquakes near the study area (Boese et al., 2012; Leitner et al., 2001), sug- 
gesting that the onset of rapid cooling reduces temperatures to conditions where brittle processes dominate and/or that fracturing associated with seismicity accentuates cooling by the infiltration of meteoric fluids to deep levels (Menzies et al., 2014).

Despite the similarities between the geothermal gradient presented here and that of Cross et al. (2015), there are significant differences in our microstructural interpretations stemming from the much larger dataset and variety of rock types examined in this study. Cross et al. (2015) interpreted that the restricted range of $\mathrm{Ti}$ concentrations in their two protomylonite samples were established rapidly, in a narrow window of temperatures $\left(450-500{ }^{\circ} \mathrm{C}\right)$ above the kink in the geothermal gradient. Alternatively, we attribute the restricted range of Ti concentrations to deformation along a constant Ti isopleth below the kink - a scenario not considered by Cross et al. (2015). In their interpretation, the microstructures are essentially a snapshot of a rapidly changing grain configuration, whereas we hypothesize that larger grains were preserved from before and throughout Alpine Fault deformation and that these grains record a history of equilibrium Ti concentrations that happens to have varied little over time. We propose the new hypothesis because of our identification of two phases of Ti-in-quartz behavior (e.g., Fig. 12). In the earlier phase (phase 1), coarse grains with a homogeneous $\mathrm{Ti}$ concentration were established (Figs. 6, 8). The development of finer grains during late phase 1 deformation was not associated with significant systematic changes in Ti concentration (e.g., Figs. 4, 8). Alternatively, phase 2, associated with ultramylonites (Figs. 3, 8) and $C^{\prime}$ fabrics (Fig. 10), is marked by decreased Ti-in-quartz concentrations in recrystallized grains as the exhumation path ceased following a constant-Ti isopleth and began crossing Ti isopleths (Fig. 11).

\section{Conclusions}

The vast majority of the mylonitic deformation of the Alpine Fault occurred while rocks were exhumed from depths of around 35 to around $8 \mathrm{~km}$ while cooling by only $120^{\circ} \mathrm{C}$ (from 600 to $480^{\circ} \mathrm{C}$ ) along a geothermal gradient of $5^{\circ} \mathrm{C} \mathrm{km}^{-1}$. Assuming a constant exhumation rate, cooling rates increased at a depth of $8 \mathrm{~km}$ by 1 order of magnitude as the geothermal gradient increased to about $60^{\circ} \mathrm{C} \mathrm{km}^{-1}$. The transition at $8 \mathrm{~km}$ corresponds roughly to the position of the knee in the geothermal gradient predicted by simple two-dimensional models of exhumed faults (Koons, 1987) as well as the lower limit of seismicity (Leitner et al., 2001; Boese et al., 2012) and the formation of ultramylonites in the fault core. Deformation at temperatures $<400^{\circ} \mathrm{C}$ was dominated by brittle processes such as cataclasis on and near (within $\sim 30 \mathrm{~m}$ of) the Alpine Fault and, until a temperature of $300{ }^{\circ} \mathrm{C}$ was reached, minor ductile deformation in protomylonites away from the fault. Despite major uncertainties in activity of $\mathrm{TiO}_{2}$, Ti-in-quartz data can provide valuable quan- titative constraints on deformation temperature and geothermal gradients.

Data availability. All isotopic data for standards and analyses, and a table compiling microstructural data for each analysis point are provided in the Supplement.

\section{The Supplement related to this article is available online at https://doi.org/10.5194/se-9-1123-2018-supplement.}

Competing interests. The authors declare that they have no conflict of interest.

Acknowledgements. We are grateful for helpful conversations with Andrew Cross. Yunbin Guan provided critical assistance with the SIMS, and Brent Pooley prepared thin sections. Funding for the project was supplied by NSF grants IRFP-1064805 and EAR-1524602.

Edited by: Renée Heilbronner

Reviewed by: Djordje Grujic and one anonymous reviewer

\section{References}

Ashley, K. T. and Law, R. D.: Modeling prograde $\mathrm{TiO}_{2}$ activity and its signicance for Ti-in-quartz thermobarometry of pelitic metamorphic rocks, Contrib. Mineral. Petr., 169, 23, https://doi.org/10.1007/s00410-015-1118-7, 2015.

Batt, G. E. and Braun, J.: On the thermomechanical evolution of compressional orogens, Geophys. J. Int., 128, 364-382, 1997.

Batt, G. E. and Braun, J.: The tectonic evolution of the Southern Alps, New Zealand: insights from fully thermally coupled dynamical modelling, Geophys. J. Int., 136, 403-420, 1999.

Batt, G. E., Braun, J., Kohn, B. P., and McDougall, I.: Thermochronological analysis of the dynamics of the Southern Alps, New Zealand, Geol. Soc. Am. Bull., 112, 250-266, 2000.

Batt, G. E., Baldwin, S. L., Cottam, M., Fitzgerald, P. G., and Brandon, M. T.: Cenozoic plate boundary evolution in the South Island of New Zealand: new thermochronological constraints, Tectonics, 23, TC4001, https://doi.org/10.1029/2003TC001527, 2004.

Behr, W. M. and Platt, J. P.: A naturally constrained stress profile through the middle crust in an extensional terrane, Earth Planet. Sc. Lett., 303, 181-192, https://doi.org/10.1016/J.Epsl.2010.11.044, 2011.

Behr, W. M., Thomas, J., and Hervig, R.: Calibrating Ti concentrations in quartz on the SIMS using NIST silicate glasses with applications to the TitaniQ geothermobarometer, Am. Mineral., 96, 1100-1106, https://doi.org/10.2138/am.2011.3702, 2010.

Bestmann, M. and Pennacchioni, G.: Ti distribution in quartz across a heterogeneous shear zone within a granodiorite: The effect of 
deformation mechanism and strain on Ti resetting, Lithos, 227, 37-56, https://doi.org/10.1016/j.lithos.2015.03.009, 2015.

Beyssac, O., Cox, S. C., Vry, J., and Herman, F.: Peak metamorphic temperature and thermal history of the Southern Alps (New Zealand), Tectonophysics, 676, 229-249, https://doi.org/10.1016/j.tecto.2015.12.024, 2016.

Boese, C. M., Townend, J., Smith, E., and Stern, T.: Microseismicity and stress in the vicinity of the Alpine Fault, central Southern Alps, New Zealand, J. Geophys. Res., 117, B02302, https://doi.org/10.1029/2011JB008460, 2012.

Boulton, C., Moore, D., Lockner, D. A., Toy, V. G., Townend, J., and Sutherland, R.: Frictional properties of exhumed fault gouges in DFDP-1 cores, Alpine Fault, New Zealand, Geophys. Res. Lett., 41, https://doi.org/10.1002/2013GL058236, 2014.

Bourguignon, S., Bannister, S., Henderson, C. M., Townend, J., and Zhang, H.: Structural heterogeneity of the midcrust adjacent to the central Alpine Fault, New Zealand: Inferences from seismic tomography and seismicity between Harihari and Ross, Geochem. Geophy. Geosy., 16, 1017-1043, https://doi.org/10.1002/2014GC005702, 2015.

Cande, S. C. and Stock, J. M.: Pacific-Antarctic-Australia motion and the formation of the Macquarie Plate, Geophys. J. Int., 157, 399-414, 2004.

Chamberlain, C. J., Shelly, D. R., Townend, J., and Stern, T. A.: Low-frequency earthquakes reveal punctuated slow slip on the deep extent of the Alpine Fault, New Zealand, Geochem. Geophy. Geosy., 15, https://doi.org/10.1002/2014GC005436, 2014.

Cherniak, D. J., Watson, E. B., and Wark, D. A.: Ti diffusion in quartz, Chem. Geol., 236, 65-74, https://doi.org/10.1016/J.Chemgeo.2006.09.001, 2007.

Cooper, A. F.: Retrograde alteration of chromian kyanite in metachert and amphibolite whiteschist from the Southern Alps, New Zealand, with implications for uplift on the Alpine Fault, Contrib. Mineral. Petr., 75, 153-164, https://doi.org/10.1007/BF00389775, 1980.

Cooper, A. F. and Ireland, T. R.: The Pounamu terrane, a new Cretaceous exotic terrane within the Alpine Schist, New Zealand; tectonically emplaced, deformed and metamor- phosed during collision of the LIP Hikurangi Plateau with Zealandia, Gondwana Res., 27, 1255-1269, https://doi.org/10.1016/j.gr.2013.11.011, 2015.

Cox, S. and Sutherland, R.: Regional Geological Framework of South Island, New Zealand, and its Signi cance for Understanding the Active Plate Boundary, in: A Continental Plate Boundary: Tectonics at South Island, New Zealand, Geophysical Monograph Series, American Geophysical Union, Washington D.C. edited by David Okaya, Tim Stern, Fred Davey, 175, 2007.

Craw, D.: Fluid inclusion evidence for geothermal structure beneath the Southern Alps, New Zealand, New Zeal. J. Geol. Geop., 40, 43-52, https://doi.org/10.1080/00288306.1997.9514739, 1997.

Cross, A. J., Kidder, S., and Prior, D.: Using quartz sheared around garnet porphyroclasts to evaluate microstructural evolution in nature, J. Struct. Geol., 75, 17-31, https://doi.org/10.1016/j.jsg.2015.02.012, 2015.

Dresen, G., Duyster, J., Stöckhert, B., Wirth, R., and Zulauf, G.: Quartz dislocation microstructure between $7000 \mathrm{~m}$ and $9100 \mathrm{~m}$ depth from the Continental Deep Drilling Program KTB, J. Geophys. Res., 102, 18443-18452, 1997.
Dunlap, W., Hirth, G., and Teyssier, C.: Thermomechanical evolution of a ductile duplex, Tectonics, 16, 983-1000, 1997.

Ellis, S. and Stöckhert, B.: Elevated stresses and creep rates beneath the brittle-ductile transition caused by seismic faulting in the upper crust, J. Geophys. Res., 109, B05407, https://doi.org/10.1029/2003JB002744, 2004.

Gillam, B. G., Little, T. A., Smith, E., and Toy, V. G.: Extensional shear band development on the outer margin of the Alpine mylonite zone, Tatare Stream, Southern Alps, New Zealand, J. Struct. Geol., 54, 1-20, https://doi.org/10.1016/j.jsg.2013.06.010, 2013.

Grapes, R. and Watanabe, T.: Metamorphism and uplift of Alpine schist in the Franz Josef-Fox Glacier area of the Southern Alps, New Zealand, Metamophic Geology, 10, 171-180, 1992.

Grapes, R. H.: Uplift and exhumation of Alpine Schist, Southern Alps, New Zealand: thermobarometric constraints, New Zeal. J. Geol. Geop., 38, 525-533, 1995.

Grujic, D., Stipp, M., and Wooden, J. L.: Thermometry of quartz mylonites: Importance of dynamic recrystallization on Ti-inquartz reequilibration, Geochem. Geophy. Geosy., 12, Q06012, https://doi.org/10.1029/2010GC003368, 2011.

Haertle, M., Herwegh, M., and Pettke, T.: Titanium-in-quartz thermometry on synkinematic quartz veins in a retrograde crustal-scale normal fault zone, Tectonophysics, 608, 468-481, https://doi.org/10.1016/j.tecto.2013.08.042, 2013.

Herman, F., Braun, J., and Dunlap, W. J.: Tectonomorphic scenarios in the Southern Alps of New Zealand, J. Geophys. Res.-Sol. Ea., 112, B04201, https://doi.org/10.1029/2004jb003472, 2007.

Hirth, G. and Tullis, J.: Dislocation creep regimes in quartz aggregates, J. Struct. Geol., 14, 145-159, 1992.

Holcombe, R. J. and Little, T. A.: A sensitive vorticity gauge using rotated porphyroblasts, and its application to rocks adjacent to the Alpine Fault, New Zealand, J. Struct. Geol., 23, 979-989, 2001.

Holm, D. K., Norris, R. J., and Craw, D.: Brittle and ductile deformation in a zone of rapid uplift: Central Southern Alps, New Zealand, Tectonics, 8, 153-168, 1989.

Huang, R. and Audétat, A.: The titanium-in-quartz (TitaniQ) thermobarometer: A critical examination and re-calibration, Geochim. Cosmochim. Ac., 84, 75-89, https://doi.org/10.1016/j.gca.2012.01.009, 2012.

Jessel, M. W.: Grain-boundary migration microstructures in a naturally deformed quartzite, J. Struct. Geol., 9, 1007-1014, https://doi.org/10.1016/0191-8141(87)90008-3, 1987.

Jochum, K. P., Weis, U., Stoll, B., Kuzmin, D., Yang, Q., Raczek, I., Jacob, D. E., Stracke, A., Birbaum, K., Frick, D. A., Günther, D., and Enzweiler, J.: Determination of Reference Values for NIST SRM 610-617 Glasses Following ISO Guidelines, Geostand. Geoanal. Res., 35, 397-429, https://doi.org/10.1111/j.1751908X.2011.00120.x, 2011.

Kalceff, M. A. S. and Phillips, M. R.: Cathodoluminescence microcharacterisation of the defect structure of quartz, Phys. Rev. B, 52, 3122-3144, 1995.

Kidder, S. B., Avouac, J. P., and Chan, Y. C.: Constraints from rocks in the Taiwan orogen on crustal stress levels and rheology, J. Geophys. Res., 117, B09408, https://doi.org/10.1029/2012JB009303, 2012.

Kidder, S., Avouac, J.-P., and Chan, Y.-C.: Application of titaniumin-quartz thermobarometry to greenschist facies veins and re- 
crystallized quartzites in the Hsüehshan range, Taiwan, Solid Earth, 4, 1-21, https://doi.org/10.5194/se-4-1-2013, 2013.

Kidder, S., Toy, V., Prior, D., and Little, T.: The Effect of Recrystallization on Titanium Concentrations in Quartz, an Example from New Zealand's Alpine Fault, American Geophysical Union Annual Meeting, 12-16 December, New Orleans, 2016a.

Kidder, S. B., Hirth, G., Avouac, J. P., and Behr, W. M.: The influence of stress history on the grain size and microstructure of experimentally deformed quartzite, J. Struct. Geol., 83, 194-206, https://doi.org/10.1016/j.jsg.2015.12.004, 2016b.

Kohlstedt, D. L., Evans, B., and Mackwell, S. J.: Strength of the lithosphere-constraints imposed by laboratory experiments, J. Geophys. Res.-Sol. Ea., 100, 17587-17602, 1995.

Kohn, M. J. and Northrup, C. J.: Taking mylonites' temperatures, Geology, 37, 47-50, https://doi.org/10.1130/G25081A.1, 2009.

Koons, P. O.: Some thermal and mechanical consequences of rapid uplift: an example from the Southern Alps, New Zealand, Earth Planet. Sc. Lett., 86, 307-319, 1987.

Kruhl, J. H.: Prism- and basal-plane parallel subgrain boundaries in quartz: a microstructural geothermobarometer, J. Metamorph. Geol., 14, 581-589, 1996.

Law, R. D.: Deformation thermometry based on quartz $c$-axis fabrics and recrystallization microstructures: A review., J. Struct. Geol., 66, 129-161, https://doi.org/10.1016/j.jsg.2014.05.023, 2014.

Leeman, W. P., MacRae, C. M., Wilson, N. C., Torpy, A., Lee, C.T. A., Student, J. J., Thomas, J. B., and Vicenzi, E. P.: A Study of Cathodoluminescence and Trace Element Compositional Zoning in Natural Quartz from Volcanic Rocks: Mapping Titanium Content in Quartz, Microsc. Microanal., 18, 1322-1341, 2012.

Leitner, B., Eberhart-Phillips, D., Anderson, H., and Nabelek, J.: A focussed look at the Alpine Fault, New Zealand: Seismicity, focal mechanisms, and stress observations, J. Geophys. Res., 106, 2193-2220, 2001.

Lindroos, Z. R.: Microstructures Developed during Creep Deformation of Quartz: an Investigation of Shape and Crystallographic Characteristics, MSc, Geology Department, University of Otago, Dunedin, New Zealand, 119 pp., 2013.

Little, T. A.: Transpressive ductile flow and oblique ramping of lower crust in a two-sided orogen: Insight from quartz grainshape fabrics near the Alpine fault, New Zealand, Tectonics, 23, TC2013, https://doi.org/10.1029/2002TC001456, 2004.

Little, T., Holcombe, R. J., and Ilg, B. R.: Ductile fabrics in the zone of active oblique convergence near the Alpine Fault, New Zealand: identifying the neotectonic overprint, J. Struct. Geol., 24, 193-217, 2002a.

Little, T. A., Holcombe, R. J., and Ilg, B. R.: Kinematics of oblique collision and ramping inferred from microstructures and strain in middle crustal rocks, central Southern Alps, New Zealand, J. Struct. Geol., 24, 219-239, 2002b.

Little, T. A., Cox, S., Vry, J. K., and Batt, G.: Variations in exhumation level and uplift rate along the obliqu-slip Alpine fault, central Southern Alps, New Zealand, Geol. Soc. Am. Bull., 117, 707-723, 2005.

Little, T. A., Prior, D. J., Toy, V. G., and Lindroos, Z. R.: The link between strength of lattice preferred orientation, second phase content and grain boundary migration: A case study from the Alpine Fault zone, New Zealand, J. Struct. Geol., 81, 59-77, https://doi.org/10.1016/j.jsg.2015.09.004 2015.
Little, T. A., Prior, D. J., and Toy, V. G.: Are quartz LPOs predictably oriented with respect to the shear zone boundary?: A test from the Alpine Fault mylonites, New Zealand, Geochem. Geophy. Geosy., 17, 981-999, https://doi.org/10.1002/2015GC006145, 2016.

Liu, Z. and Bird, P.: Finite element modeling of neotectonics in New Zealand, J. Geophys. Res., 107, 2328, https://doi.org/10.1029/2001JB001075, 2002.

MacRae, C. M., Wilson, N. C., and Torpy, A.: Hyperspectral cathodoluminescence, Miner. Petrol., 107, 429-440, https://doi.org/10.1007/s00710-013-0272-8, 2013.

Menzies, C. D., Teagle, D. A. H., Craw, D., Cox, S. C., Boyce, A. J., Barrie, C. D., and Roberts, S.: Incursion of meteoric waters into the ductile regime in an active orogen, Earth Planet. Sc. Lett., 2014, 1-13, https://doi.org/10.1016/j.epsl.2014.04.046, 2014.

Nachlas, W. and Hirth, G.: Experimental constraints on the role of dynamic recrystallization on resetting the Ti-in-quartz thermobarometer, J. Geophys. Res., 120, https://doi.org/10.1002/2015JB012274, 2015.

Nachlas, W., Whitney, D., Teyssier, C., Bagley, B., and Mulch, A.: Titanium concentration in quartz as a record of multiple deformation mechanisms in an extensional shear zone, Geochem. Geophy. Geosy., 15, 1374-1397, https://doi.org/10.1002/2013GC005200, 2014.

Nevitt, J. M., Warren, J. M., Kidder, S., and Pollard, D. D.: Comparison of thermal modeling, microstructural analysis, and Ti-in-quartz thermobarometry to constrain the thermal history of a cooling pluton during deformation in the Mount Abbot Quadrangle, CA, Geochem. Geophy. Geosy., 18, 1270-1297, https://doi.org/10.1002/2016GC006655, 2017.

Niemeijer, A. R., Boulton, C., V. G., T., Townend, J., and Sutherland, R.: Large-displacement, hydrothermal frictional properties of DFDP-1 fault rocks, Alpine Fault, New Zealand: Implications for deep rupture propagation, J. Geophys. Res.-Sol. Ea., 121, 624-647, https://doi.org/10.1002/2015JB012593, 2016.

Norris, R. and Cooper, A.: The Alpine Fault, New Zealand: Surface Geology and Field Relationships, American Geophysical Union, 157-175, https://doi.org/10.1029/175GM09, 2007.

Norris, R. and Toy, V.: Continental transforms: A view from the Alpine Fault, J. Struct. Geol., 64, 3-31, https://doi.org/10.1016/j.jsg.2014.03.003, 2014.

Norris, R. J. and Cooper, A. F.: Very high strains recorded in mylonites along the Alpine Fault, New Zealand: implications for the deep structure of plate boundary faults, J. Struct. Geol., 25, 2141-2157, 2003.

Shi, Y. L., Allis, R., and Davey, F.: Thermal modeling of the Southern Alps, New Zealand, Pure Appl. Geophys., 146, 469-501, 1996.

Sibson, R. H.: Fault rocks and fault mechanisms, J. Geol. Soc. London, 133, 191-213, 1977.

Sibson, R. H., White, S. H., and Atkinson, B. K.: Fault rock distribution and structure within he Alpine Fault Zone: A Preliminary Account, Royal Society of New Zealand Bulletin, 18, 5565, 1979.

Sibson, R. H., White, S. H., and Atkinson, B. K.: Structure and distribution of fault rocks in the Alpine Fault Zone, New Zealand, Geol. Soc. S. P., 9, 197-210, https://doi.org/10.1144/GSL.SP.1981.009.01.18, 1981. 
Spear, F. S.: Metamorphic phase equilibria and pressuretemperature-time paths, Mineralogical Society of America, Washington, D.C., USA, 1995.

Spear, F. S., Ashley, K. T., Webb, L. E., and Thomas, J. B.: Ti diffusion in quartz inclusions: implications for metamorphic time scales, Contrib. Mineral. Petr., 977-986, https://doi.org/10.1007/s00410-012-0783-z, 2012.

Stern, T., Okaya, D., Kleffmann, S., Scherwath, M., Henrys, S., and Davey, F.: Geophysical Exploration and Dynamics of the Alpine Fault Zone, A Continental Plate Boundary: Tectonics at South Island, New Zealand, Geophysical Monograph Series 175, published by American Geophysical Union, Washington D.C., edited by: Okaya, D., Stern, T., and Davey, F., https://doi.org/10.1029/175GM11, 2007.

Stipp, M., Stünitz, H., Heilbronner, R., and Schmid, S. M.: Dynamic recrystallization of quartz: correlation between natural and experimental conditions, Geol. Soc. S. P., 200, 171-190, 2002.

Stöckhert, B., Brix, M. R., Kleinschrodt, R., Hurford, A. J., and Wirth, R.: Thermochronometry and microstructures of quartz - a comparison with experimental flow laws and predictions on the temperature of the brittle-plastic transition, J. Struct. Geol., 21, 351-369, 1999.

Sutherland, R., Davey, F., and Beavan, J.: Plate boundary deformation in South Island, New Zealand, is related to inherited lithospheric structure, Earth Planet. Sc. Lett., 177, 141-151, 2000.

Sutherland, R., Eberhart-Phillips, D., Harris, R. A., Stern, T., Beavan, J., Ellis, S., Henrys, S., cox, S., norris, R., Berryman, K., Townend, J., Bannister, S., Pettinga, J., Leitner, B., Wallace, L., Little, T., cooper, A. F., Yetton, M., and Stirling, M.: Do Great Earthquakes occur on the Alpine Fault in central South Island, new Zealand?, in: A Continental Plate Boundary: Tectonics at South Island, New Zealand, Geophysical Monograph Series 175, published by American Geophysical Union, Washington D.C., edited by: Okaya, D., Stern, T., and Davey, F., 175, 2007.

Sutherland, R., Toy, V. G., Townend, J., Cox, S. C., Eccles, J. D., Faulkner, D. R., Prior, D. J., Norris, R. J., Mariani, E., Boulton, C., Carpenter, B. M., Menzies, C. D., Little, T. A., Hasting, M., Pascale, G. P. D., Langridge, R. M., Scott, H. R., Reid, Z., Lindroos, Fleming, B., and Kopf, A. J.: Drilling reveals fluid control on architecture and rupture of the Alpine fault, New Zealand, Geology, 40, 1143-1146, https://doi.org/10.1130/G33614.1, 2012.

Sutherland, R., Townend, J., Toy, V., Upton, P., Coussens, J., Allen, M., Baratin, L.-M., Barth, N., Becroft, L., Boese, C., Boles, A., Boulton, C., Broderick, N. G. R., Janku-Capova, L., Carpenter, B. M., Ceìleìrier, B., Chamberlain, C., Cooper, A., Coutts, A., Cox, S., Craw, L., Doan, M.-L., Eccles, J., Faulkner, D., Grieve, J., Grochowski, J., Gulley, A., Hartog, A., Howarth, J., Jacobs, K., Jeppson, T., Kato, N., Keys, S., Kirilova, M., Kometani, Y., Langridge, R., Lin, W., Little, T., Lukacs, A., Mallyon, D., Mariani, E., Massiot, C. c., Mathewson, L., Melosh, B., Menzies, C., Moore, J., Morales, L., Morgan, C., Mori, H., Niemeijer, A., Nishikawa, O., Prior, D., Sauer, K., Savage, M., Schleicher, A., Schmitt, D. R., Shigematsu, N., Taylor-Offord, S., Teagle, D., Tobin, H., Valdez, R., Weaver, K., Wiersberg, T., Williams, J., Woodman, N., and Zimmer, M.: Extreme hydrothermal conditions at an active plate-bounding fault, Nature, 546, 137-140, https://doi.org/10.1038/nature22355, 2017.

Thomas, J. B., Watson, E. B., Spear, F. S., Shemella, P. T., Nayak, S. K., and Lanzirotti, A.: TitaniQ under pressure: the effect of pres- sure and temperature on the solubility of $\mathrm{Ti}$ in quartz, Contrib. Mineral. Petr., 160, 743-759, https://doi.org/10.1007/s00410010-0505-3, 2010.

Thomas, J. B., Watson, E. B., Spear, F. S., and Wark, D. A.: TitaniQ recrystallized: experimental confirmation of the original Ti-in-quartz calibrations, Contrib. Mineral. Petr., 169, 27, https://doi.org/10.1007/s00410-015-1120-0, 2015.

Toy, V. G.: Rheology of the Alpine Fault Mylonite Zone: deformation processes at and below the base of the seismogenic zone in a major plate boundary structure, $\mathrm{PhD}$, Geology Department, University of Otago, Dunedin, New Zealand, 629 pp., 2007.

Toy, V. G., Prior, D. J., and Norris, R. J.: Quartz fabrics in the Alpine Fault mylonites: Influence of pre-existing preferred orientations on fabric development during progressive uplift, J. Struct. Geol., 30, 602-621, 2008.

Toy, V. G., Craw, D., Cooper., A. F., and Norris, R. J.: Thermal regime in the central Alpine Fault zone, New Zealand: Constraints from microstructures, biotite chemistry, and fluid inclusion data, Tectonophysics, 485, 178-192, https://doi.org/10.1016/j.tecto.2009.12.013, 2010.

Toy, V. G., Prior, D. J., Norris, R. J., Cooper, A. F., and Walrond, M.: Relationships between kinematic indicators and strain during syn-deformational exhumation of an oblique slip, transpressive, plate boundary shear zone: The Alpine Fault, New Zealand, Earth Planet. Sc. Lett., 333-334, 282-292, https://doi.org/10.1016/j.epsl.2012.04.037, 2012.

Toy, V. G., Norris, R. J., Prior, D. J., Walrond, A. F., and Cooper, A. F.: How do lineations reflect the strain history of transpressive shear zones? The example of the active Alpine Fault zone, New Zealand, J. Struct. Geol., 50, 187-198, https://doi.org/10.1016/j.jsg.2012.06.006, 2013.

Toy, V. G., Boulton, C. J., Sutherland, R., Townend, J., Norris, R. J., Little, T. A., Prior, D. J., Mariani, E., Faulkner, D., Menzies, C. D., Scott, H., and Carpenter, B. M.: Fault rock lithologies and architecture of the central Alpine fault, New Zealand, revealed by DFDP-1 drilling, Lithosphere, 7, 155-173, https://doi.org/10.1130/L395.1, 2015.

van Daalen, M., Heilbronner, R., and Kunze, K.: Orientation analysis of localized shear deformation in quartz fibres at the brittleductile transition, Tectonophysics, 303, 83-107, 1999.

Vry, J., Baker, J., Maas, R., Little, T. A., Grapes, R., and Dixon, M.: Zoned (Cretaceous and Cenozoic) garnet and the timing of high grade metamorphism, Southern Alps, New Zealand, J. Metamorph. Geol., 22, 137-157, https://doi.org/10.1111/j.15251314.2004.00504.x, 2004.

Vry, J. K., Powell, R., and Williams, J.: Establishing the P-T path for Alpine Schist, Southern Alps near Hokitika, New Zealand, J. Metamorph. Geol., 26, 81-97, 2007.

Walcott, R. I.: Present tectonics and late Cenozoic evolution of New Zealand, Rev. Geophys., 36, 1-26, 1998.

Wark, D. and Spear, F.: Ti in quartz: Cathodoluminescence and thermometry, Goldschmidt, Moscow, Idaho, A592, 2005.

Wark, D. A. and Watson, B.: TitaniQ: a titanium-inquartz geothermometer, Contrib. Mineral. Petr., 152, https://doi.org/10.1007/s00410-006-0132-1, 743-754, 2006. 